Review

\title{
Non-perennial Mediterranean rivers in Europe: Status, pressures, and challenges for research and management
}

\author{
Nikolaos T. Skoulikidis a , Sergi Sabater ${ }^{\mathrm{b}, \mathrm{j}}$, Thibault Datry ${ }^{\mathrm{c}}$, Manuela M. Morais ${ }^{\mathrm{d}}$, Andrea Buffagni ${ }^{\mathrm{e}}$, \\ Gerald Dörflinger $^{\mathrm{f}}$, Stamatis Zogaris ${ }^{\mathrm{a}}$, Maria del Mar Sánchez-Montoya ${ }^{\mathrm{g}}$, Nuria Bonada ${ }^{\mathrm{h}}$, Eleni Kalogianni ${ }^{\mathrm{a}}$, \\ Joana Rosado ${ }^{\mathrm{i}}$, Leonidas Vardakas ${ }^{\mathrm{a}, *}$, Anna Maria De Girolamo ${ }^{\mathrm{e}}$, Klement Tockner ${ }^{\mathrm{g}}$ \\ a Hellenic Centre for Marine Research, Institute of Marine Biological Resources and Inland Waters, 46.7 km Athens-Sounion Ave., 19013 Anavyssos, Attica, Greece \\ b Catalan Institute for Water Research (ICRA), Emili Grahit 101, 17003 Girona, Spain \\ c IRSTEA, UR-MALY, centre de Lyon-Villeurbanne, 5 rue de la Doua CS70077, FR-69626 Villeurbanne Cedex, France \\ ' Dept. Biology, Institute of Earth Sciences (ICT), University of Évora, Largo dos Colegiais, 7000 Évora, Portugal \\ e IRSA-CNR, Water Research Institute, National Research Council of Italy, Rome, Italy \\ ${ }^{\mathrm{f}}$ Water Development Department, 100-110 Kennenty Avenue, Pallouriotissa, 1047 Lefkosia, Cyprus \\ g Leibniz-Institute of Freshwater Ecology and Inland Fisheries, Müggelseedamm 310, 12587 Berlin, Germany

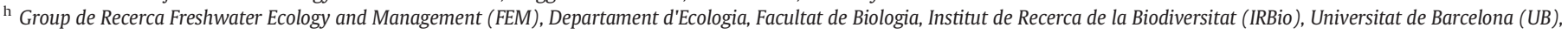 \\ Diagonal 643, 08028 Barcelona, Catalonia, Spain \\ i Institute of Earth Sciences (ICT), University of Évora, Largo dos Colegiais, 7000 Évora, Portugal \\ j GRECO, Institute of Aquatic Ecology, University of Girona, Campus Montilivi, 17003 Girona, Spain
}

\section{H I G H L I G H T S}

- Low precipitation and increasing water demands in the EU-Med area have created artificial non-perennial rivers and streams.

- NPRS are particularly vulnerable since they lack adequate protection and management.

- To combat artificial drying, we need to define alternatives to existing irrigated farming practices for EU-Med countries.

\section{G R A P H I C A L A B S T R A C T}
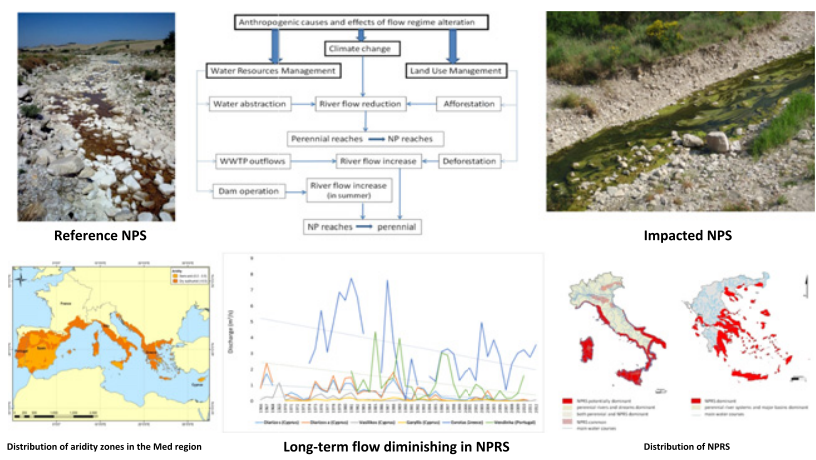

Impacted NPS

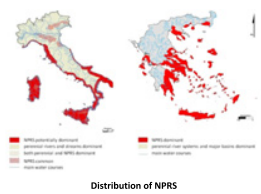

Distribution of NPRs

\section{A R T I C L E I N F O}

\section{Article history:}

Received 2 July 2016

Received in revised form 15 October 2016

Accepted 16 October 2016

Available online 31 October 2016

Editor: D. Barcelo

\section{Keywords:}

Non-perennial (temporary, intermittent,

\section{A B S T R A C T}

Non-perennial rivers and streams (NPRS) cover $>50 \%$ of the global river network. They are particularly predominant in Mediterranean Europe as a result of dry climate conditions, climate change and land use development. Historically, both scientists and policy makers underestimated the importance of NRPS for nature and humans alike, mainly because they have been considered as systems of low ecological and economic value. During the past decades, diminishing water resources have increased the spatial and temporal extent of artificial NPRS as well as their exposure to multiple stressors, which threatening their ecological integrity, biodiversity and ecosystem services. In this paper, we provide a comprehensive overview of the structural and functional characteristics of NPRS in the European Mediterranean, and discuss gaps and problems in their management, concerning their typology, ecological assessment, legislative and policy protection, and incorporation in River Basin Management

\footnotetext{
* Corresponding author

E-mail address: louisvard@gmail.com (L. Vardakas).
} 
ephemeral) rivers and streams

Climate

Pressures

Hydrology

Hydrobiology

Biogeochemistry

Management

WFD
Plans. Because NPRS comprise highly unstable ecosystems, with strong and often unpredictable temporal and spatial variability - at least as far as it is possible to assess - we outline the future research needs required to better understand, manage and conserve them as highly valuable and sensitive ecosystems. Efficient collaborative activities among multidisciplinary research groups aiming to create innovative knowledge, water managers and policy makers are urgently needed in order to establish an appropriate methodological and legislative background. The incorporation of NPRS in EU-Med River Basin Management Plans in combination with the application of ecological flows is a first step towards enhancing NPRS management and conservation in order to effectively safeguard these highly valuable albeit threatened ecosystems.

(C) 2016 Elsevier B.V. All rights reserved.

\section{Contents}



2. Pressures and impacts in non-perennial EU-med streams . . . . . . . . . . . . . . . . . . . . . . . . . . . . . . . . . . . . . . . . . 3

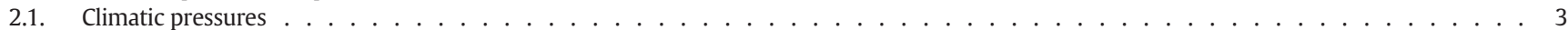

2.2. Anthropogenic pressures . . . . . . . . . . . . . . . . . . . . . . . . . . . . . . . . . . . 3

2.3. Climate and anthropogenic impacts . . . . . . . . . . . . . . . . . . . . . . . . . . . . . . . . . . 5

2.3.1. Hydrological impacts . . . . . . . . . . . . . . . . . . . . . . . . . . . . . . . . . . . . . . 5

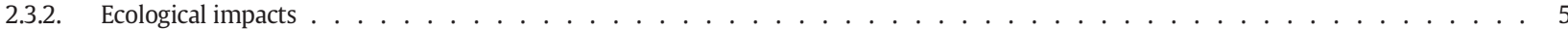

3. Evolution and current state of EU-Med NPRS research and management . . . . . . . . . . . . . . . . . . . . . . . . . . . . . . . . . . . . 6



3.2. Specific research achievements in EU-Med NPRS. . . . . . . . . . . . . . . . . . . . . . . . . . . . . . . . . . . . . . . . . . . 8

3.2.1. Geographical distribution of NPRS . . . . . . . . . . . . . . . . . . . . . . . . . . . . . . . . . . . . . . . . . . 8

3.2.2. Pressures and impacts . . . . . . . . . . . . . . . . . . . . . . . . . . . . . . . . . . . . . 8

3.2.3. Hydrological processes . . . . . . . . . . . . . . . . . . . . . . . . . . . . . . . . . . . . 8

3.2.4. Biotic responses to flow intermittency . . . . . . . . . . . . . . . . . . . . . . . . . . . . . . . . . 8

3.2.5. Hydromorphology vs ecological quality. . . . . . . . . . . . . . . . . . . . . . . . . . . . . . . . . . . . . . . . . 9

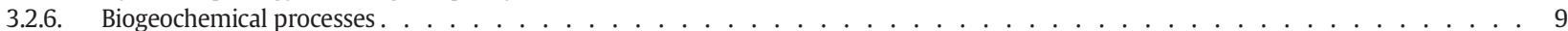

3.3. Management in EU-Med NPRS . . . . . . . . . . . . . . . . . . . . . . . . . . . . . . . . . . . . . . . . . . . . . . . . 10

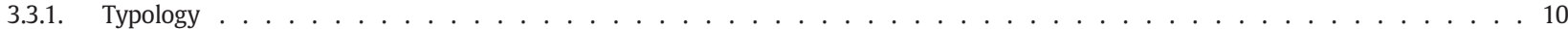

3.3.2. Ecological classification . . . . . . . . . . . . . . . . . . . . . . . . . . . . . . . . . . . . . . . 10

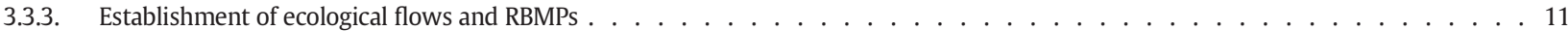

4. Future perspectives . . . . . . . . . . . . . . . . . . . . . . . . . . . . . . . . . . 12

4.1. Basic research priorities . . . . . . . . . . . . . . . . . . . . . . . . . . . . . . . . . . . . . . . 12

4.1.1. Hydrological research needs (estimation and restoration of natural flow regimes) . . . . . . . . . . . . . . . . . . . . 12

4.1.2. Biological research challenges . . . . . . . . . . . . . . . . . . . . . . . . . . . . . . . . . . . . . . . . . . . 12

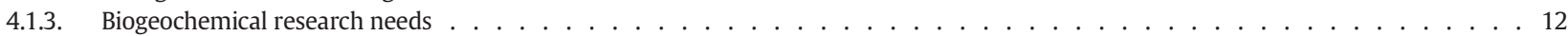

4.2. Applied research priorities. . . . . . . . . . . . . . . . . . . . . . . . . . . . . . . . . . . . . . . . . 13

4.2.1. Definition and mapping. . . . . . . . . . . . . . . . . . . . . . . . . . . . . . . . . . . . 13

4.2.2. Monitoring .. . . . . . . . . . . . . . . . . . . . . . . . . . . . . . . . . . 13

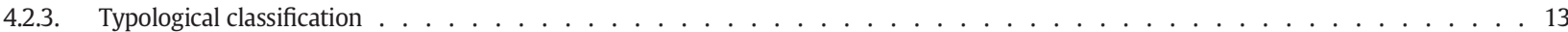

4.2.4. Development of appropriate metrics for ecological status assessment . . . . . . . . . . . . . . . . . . . . . . . . . . 13

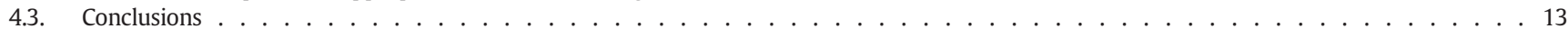

Acknowledgments . . . . . . . . . . . . . . . . . . . . . . . . . . . . . . . . . . . . . . . . . 14

References. . . . . . . . . 14

\section{Introduction}

Lotic freshwaters are either perennial or temporary (or non-perennial), according to surface flow conditions. Perennial rivers and streams (herein PRS) flow throughout the year, whereas temporary systems (herein non-perennial rivers and streams, NPRS) cease to flow at the surface for some time of the year. Depending on the specific flow regime, NPRS can be classified, according to the most common perceptions, as intermittent, ephemeral or episodic. Intermittent rivers cease to flow seasonally or occasionally (usually for weeks to months); Ephemeral streams flow only in response to precipitation or snowmelt events (days to weeks); Episodic streams carry surface water only during very short periods (hours to days), primarily after heavy rainfall events (McDonough et al., 2011; Arthington et al., 2014).

NPRS are among the most dynamic, complex and diverse freshwater systems (Larned et al., 2010; Acuña et al., 2014). They are located in all regions worldwide, and they are by far the most dominant river type in arid and semi-arid areas (Larned et al., 2010; McDonough et al., 2011; Acuña et al., 2014). NPRS may account for $>50 \%$ of the total lenght of the global river network, including low order streams (Datry et al., 2014a). In Mediterranean regions, NPRS are the dominant freshwater type (Tockner et al., 2009; Bonada and Resh, 2013). They encompass remarkable hydrogeomorphological diversity, including snow-melt and rain-fed headwater streams, spring-fed karstic rivers and streams, braided channel networks, as well as single-thread upland streams and lowland rivers.

NPRS provide habitat for a diverse and unique flora and fauna (Meyer et al., 2007; Larned et al., 2010; Bonada and Resh, 2013; Acuña et al., 2014). They function as biogeochemical hotspots that retain, transform, and transfer carbon, nutrients and particulate matter (Larned et al., 2010; McDonough et al., 2011; Bernal et al., 2013; Datry et al., 2014a). In Mediterranean cultures, "dry rivers" are very wellknown in society, reflected by various popular names: ribeiras in Portugal, arroyos, cañadas or ramblas in Spain, and rambles, torrents, rieres and 
rierols in the eastern part of the Iberian Peninsula and Balearic Islands (Vidal-Abarca, 1990), cours d' eau intermittent or ravines in France, torrenti, rii and fiumare in Italy, and xiropotamos, xeropotamos or xeros potamos in Greece and Cyprus.

The Mediterranean region is considered a global hotspot of biodiversity, endemism, and related ecosystem services (Cowling et al., 1996; Myers et al., 2000; Bonada et al., 2007a; Cuttelod et al., 2008; Tierno de Figueroa et al., 2013). At the same time, it contains the highest proportion of threatened freshwater species in Europe (Tockner et al., 2009) which are among the most endangered species worldwide (Myers et al., 2000; Cooper et al., 2013; Darwall et al., 2014).

Water use and management practices in the Mediterranean region were historically adapted to natural water scarcity (Grantham et al., 2013). However, rising water demand for agricultural, industrial, urban and touristic development have exerted widespread pressures on water resources (Bradford, 2000), which fundamentally affect the natural flow regime (Smith, 1997; UNEP/MAP, 2003; Ludwig et al., 2009; Skoulikidis, 2009). The natural seasonal dryness regime is exacerbated by human activities, and natural PRS are converted into NPRS (Datry et al., 2014a). These rivers and streams are considered "artificially dry" or "artificially intermittent" (Benejam et al., 2010; Skoulikidis et al., 2011). On the other hand, natural NPRS may be transformed into PRS after receiving effluents from Wastewater Treatmennt Plants (WWTPs) or urban and industrial discharges (Hassan and Egozi, 2001). Artificial flow regime alterations enhance the risk of unanticipated ecological changes (Poff and Zimmerman, 2010; Sabater and Tockner, 2010).

Historically, European Mediterranean (EU-Med) NPRS have been undervalued by both water managers and ecologists (Larned et al., 2010; Nikolaidis et al., 2013), and they remain among the least studied freshwater ecosystems worldwide (Uys and O'Keeffe, 1997; Jacobson et al., 2004; Ryder and Boulton, 2005; TempQsim Consortium, 2006; Acuña et al., 2014; Datry et al., 2014a). This corresponds to the widespread societal view that, according to Sabater et al. (2009) "People in arid and semi-arid regions have the least respect towards rivers, since the rivers are often dry or have catastrophic floods, and are therefore viewed more as a danger than as a natural resource to be preserved". This is particularly evident in urban areas, where they have been frequently covered by roads, with some NPRS being today important avenues of EU-Med cities (e.g. the "Ramblas" in Barcelona, Spain, the Ilissos and Iridanos streams in Athens, Greece, etc). In addition, NPRS in the EU-Med countries have been used, and are still being used, as waste disposal sites, drains for sewage effluents, roads, car parking areas and quarries for sand and gravel. Moreover, legal and illegal constructions along NPRS courses, especially along episodic ones, are common. The subsequent destructive consequences of these practices are perceived by the public only after catastrophic floods.

Recently, however, NPRS research has emerged as a multidisciplinary domain that integrates biology, ecology, biogeochemistry, hydrology, geomorphology, and river management (Larned et al., 2010; Leigh et al., 2015a). Several special issues have been published on this topic in scientific journals (e.g. Nadeau and Rains, 2007; Datry et al., 2011; Bonada and Resh, 2013), thereby advancing the perception and understanding of NPRS.

Targeting the EU-Med NPRS, the present article focuses on climatic and anthropogenic pressures, as well as the related hydrological and ecological impacts, outlines the evolution and current state of research, presents management achievements and problems, identifies knowledge gaps and research needs, and proposes future avenues for research and management to safeguard these pivotal albeit undervalued and threatened ecosystems.

\section{Pressures and impacts in non-perennial EU-med streams}

\subsection{Climatic pressures}

The Mediterranean area is characterized by high temporal climate variation, with low precipitation during summer. When applying the
"Mediterranean climate" classification scheme, according to the global climate assessment approach developed by Köppen (1936), the EUMed area fits into the dry sub-humid $(0.50<\mathrm{P} / \mathrm{PET}<0.65)$ and semiarid $(0.20<\mathrm{P} / \mathrm{PET}<0.50)$ climate zones $(\mathrm{P} / \mathrm{PET}$ : Precipitation/Potential Evaportanspiration), (UNEP, 1992; Fig. 1).

Under these climatic conditions, many Mediterranean rivers naturally exhibit a non-perennial flow regime, with a distinct seasonal, inter-annual and spatial heterogeneity (Bonada and Resh, 2013). At the same time, the Mediterranean river basins are turning drier (annual precipitation decreased up to $20 \%$ during the 20th century), with more extreme events than a century ago (EC-JRC, 2005; EEA, 2008; García-Ruiz et al., 2011).

In Southern Portugal, river basins exhibit an average annual rainfall of $<700 \mathrm{~mm}$. Due to the lack of major aquifers, the average summer runoff is $<10 \%$ of the average annual runoff (Afonso, 2007). There, NPRS are by far the most dominant watercourse type, with up to four dry months per year (INAG, 2001). Only large rivers, such as Guadiana, Sado and Mira, are perennial. The increasing frequency and intensity of droughts during the past 70 years has amplified the extent of artificial NPRS in the region (Afonso, 2007; Costa and Soares, 2009).

The south-eastern part of Spain belongs to the driest regions in Europe, with a mean precipitation of $120 \mathrm{~mm}_{\text {year }}{ }^{-1}$, and summer temperatures reaching up to $47^{\circ} \mathrm{C}$ (Estrela and Vargas, 2012). As a result, approximately $98 \%$ of the mapped water courses in the province of Murcia, which covers the driest part of the Iberian Peninsula, are NPRS (Gómez et al., 2005). Flow intermittency is further triggered by extended periods of low rainfall (Esteban-Parra et al., 1998) and high air temperature (De Castro et al., 2005).

In France, NPRS represent 20\% to 39\% of the river network. NPRS are common in regions with low annual rainfall, high air temperature and steep, small and elongated catchments, which are not restricted to the dry Mediterranean region (Snelder et al., 2013). In some areas a strong decrease of the groundwater table has caused surface drying of entire river sections (EEA, 2009).

In Italy, the mean annual precipitation drops to below $500 \mathrm{~mm}$ year $^{-1}$ in areas such as Puglia, Sicily, and Sardinia (Gumiero et al., 2009). In Sardinia and Sicily, up to $90 \%$ of all rivers are NPRS (Mulas et al., 2009; Regione Siciliana, 2010; Fig. 2).

Greece exhibits a strong N-S gradient, with increasing temperature and evapotranspiration and decreasing precipitation towards the $\mathrm{W}-\mathrm{E}$ and S-SE (Dalezios et al., 2002). There, the mean annual precipitation drops to $400 \mathrm{~mm}$. Thus, in large parts of southeastern (Attika, Eastern Peloponnese and Crete) and eastern (Aegean Islands) Greece, semiarid conditions prevail (Yassoglou et al., 1964). Though difficult to assess with accuracy, it has been stated that only 45 out of the 765 recorded rivers and streams are permanently flowing (Ministry for Development, 2003), with NPRS catchments covering approximately $40 \%$ of the entire country (Fig. 2). This proportion may rise further because droughts are becoming longer and more intense (Livada and Asimakopoulos, 2005).

Cyprus is the most arid country in the European Union, with an average annual precipitation of $460 \mathrm{~mm}$ (Department of Meteorology of Cyprus, 2014). During the past century, average annual precipitation has decreased by $17 \%$, and from 1976 to 2006, evapotranspiration has increased by $60-80 \mathrm{~mm}$ (Petrakis et al., 2012). Perennial river reaches in Cyprus are restricted to the upland areas of the central Troodos massif, while there is not a single river on the island with perennial flow along its entire course. Only $14 \%$ of the total river length is perennial, whereas $48 \%$ of the total length exhibits an intermittent and $38 \%$ an ephemeral/episodic flow regime (ENVECO S.A. and I.A.CO Ltd., 2013).

\subsection{Anthropogenic pressures}

Long-lasting human activities and rapid urban and agricultural developments have led to a large-scale conversion of riparian areas into agricultural land, massive booms in reservoir and flood control 


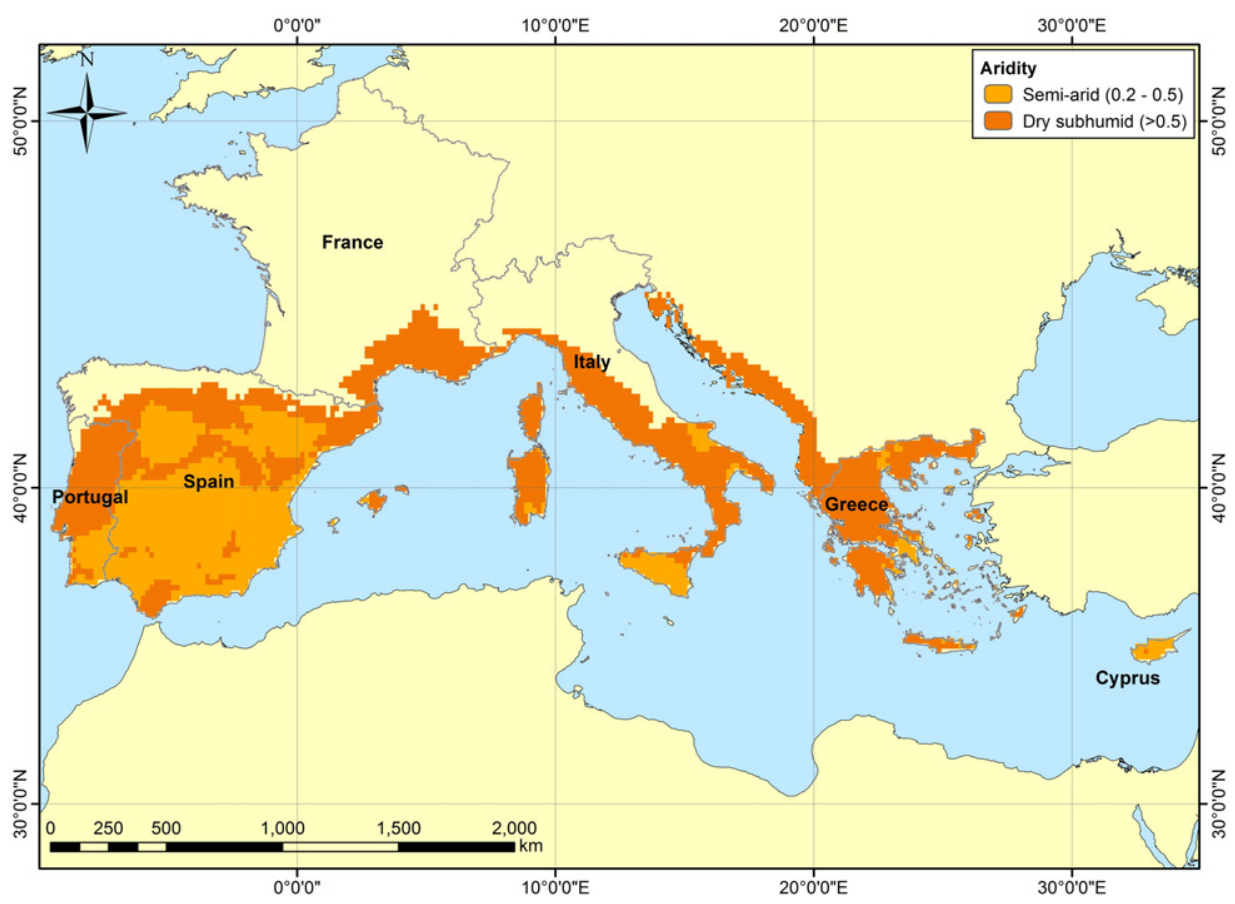

Fig. 1. Map of Europe, delineating the Mediterranean Bio-geographical Region (EEA, 2016), including the distribution of aridity zones according to UNEP (1992).

constructions, and an extensive use of water for irrigation. Today, agricultural land covers vast areas of the EU-Med region, ranging from $30 \%$ in Greece to $48 \%$ in Italy, with most farmlands being now irrigated (http://ec.europa.eu/eurostat/statistics-explained/index.php/Main_ Page). Irrigated agriculture accounts for $>60 \%$ of total water abstraction, with up to $89 \%$ in Greece (INAG, 2001). In most EU-Med countries, irrigation water is mainly obtained from rivers and streams, covering $64 \%$ (France) to $100 \%$ (Portugal) of the demand. In Cyprus, however, groundwater abstraction is the dominant water source for irrigation (81\%; Zoumides et al., 2013).

Groundwater abstraction also contributes to surface water desiccation, through the lowering of groundwater tables, while sea water intrusion in groundwater aquifers at coastal areas may affect the salt content of surface runoff. Over the last 40 years, groundwater overexploitation in the southern part of Spain has had an enormous ecological impact
(Ibáñez and Carola, 2010), related to significant lowering of groundwater tables, drying out of springs, degradation of wells and boreholes, and salt-water intrusion. For example, in the Guadiana basin since the 1960s, groundwater aquifers were overexploited for irrigation, with regulations on abstraction being only partially enforced, because of resistance by farmers (Sabater et al., 2009). In the Pinios River basin (Central Greece), intensive agriculture has caused the lowering of the groundwater tables by tens of meters (Loukas et al., 2007), facilitating the widespread desiccation of entire river sections (Stefanidis et al., 2016). In France, there are chronic imbalances between withdrawals and water resources available in a number of river basins (EEA, 2009), also very common in several coastal aquifers of Italy (Antonellini et al., 2008). In coastal areas of Sardinia, Apulia, the Catanian Plain of Sicily, the Tiber Delta, Versilia, and the Po Plain, groundwater resources are becoming scarcer due to drought, overexploitation and salinization (EEA,
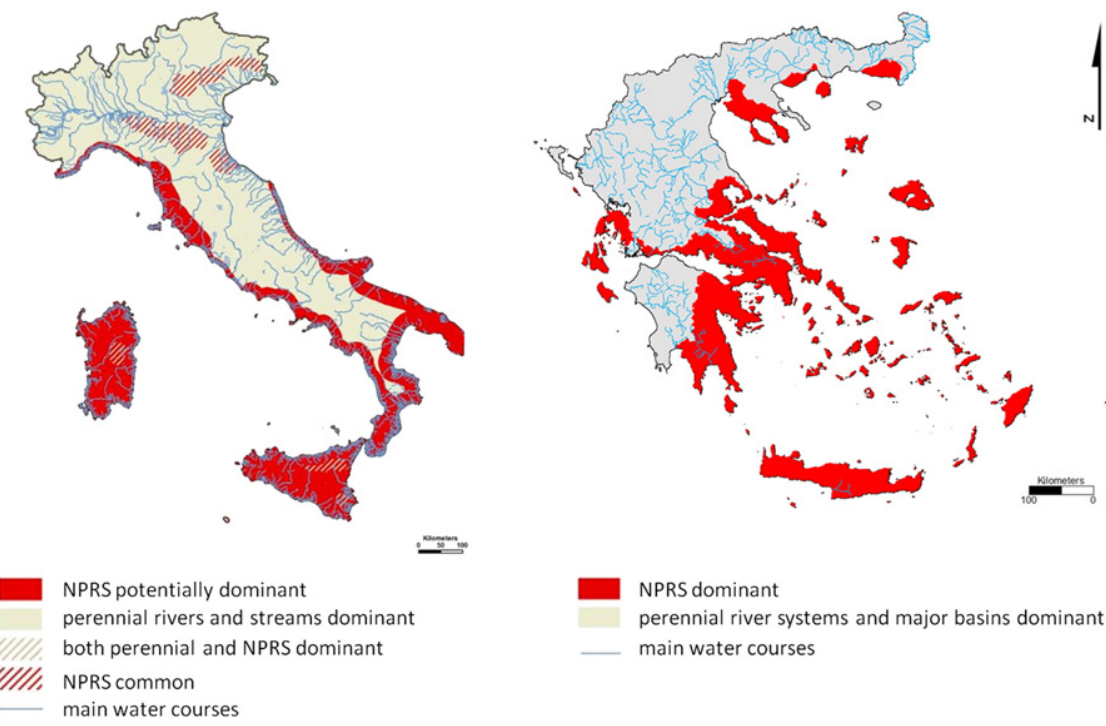

NPRS dominant

perennial river systems and major basins dominant main water courses

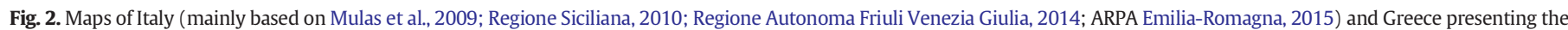
tentative distribution of NPRS basin areas. 
2012). Similarly, the majority of important aquifers in the coastal areas of Greece are subject to salinization by seawater encroachment, due to physical mechanisms and overexploitation, and large quantities of groundwater have deteriorated. In Cyprus, too, the majority of aquifers are overexploited (Georgiou, 2002), with 57\% of them being in bad quantitative status (LDK Consultants S.A. and Ecos Consulting S.A., 2015), with seawater intrusion occuring since the early 1980s (Milnes and Renard, 2004; Milnes, 2011). Finally, long dry periods impair further groundwater quality (Lambrakis and Marinos, 2005).

At the same time, coastal economic and touristic development contributes to an increasing water use, particularly in water scarce areas and during specific seasons.

To compensate for the decrease in water resources and to secure water supply during summer, numerous reservoirs have been constructed in the EU-Med during the past decades, favoured by the high topographic relief of the area (Conacher and Sala, 1998). However, this has led to the fragmentation of most rivers entering the Mediterranean Sea (Tockner et al., 2009). In Cyprus, for example, 67\% of the overall mean annual surface runoff discharges into reservoirs (Rossel, 2002). Spain has the highest number of large dams of all EU-Med countries, $\mathrm{Cy}$ prus has the highest density (Table 1), whereas the highest dams are located in Italy and Greece. Some reservoirs that are currently at the planning stage are facing considerable resistance by the civil society. The Portuguese plan for hydropower development (PNBEPH) will entail the loss of several rivers in the northern part of the country. The Mesochora Dam, located in the Upper Acheloos River (Greece), comprises one of the largest and most controversial river diversion projects in the EU-Med. The Acheloos already contains six reservoirs, which cover a total surface area of up to $150 \mathrm{~km}^{2}$. The total storage capacity is $\sim 6.6 \mathrm{~km}^{3}$, corresponding to $\sim 1.5$ times the total annual river discharge (Skoulikidis, 2009).

Inadequate ecological flows together with vast hydromorphological alterations commonly amplify the effects of a variety of other stressors, such as organic and inorganic pollution, pathogens and invasive species (Vörösmarty et al., 2010), where reduced dilution plays a pivotal role (Petrovic et al., 2011). This results in the simultaneous exposure of EU-Med NPRS ecosystems in multi-stress situations which may produce novel and unfamiliar synergies and, most likely, very pronounced effects of unknown consequence (Navarro-Ortega et al., 2015).

\subsection{Climate and anthropogenic impacts}

\subsubsection{Hydrological impacts}

A combination of extensive water abstraction, river fragmentation, and climate change has dramatically reduced river runoff in most EUMed rivers during the past decades (UNEP/MAP, 2003). The majority of the rivers of the Balkan Peninsula, for example, experienced on average a $22 \%$ reduction in initial river discharge (data: Skoulikidis, 2009). At the same time, the long-term decrease of flow in NPRS is alarming (Fig. 3; see Fig. 4 for an outline of the most common anthropogenic causes of flow regime alteration in the EU-Med region). This decrease favours the creation of disconnected pools and increases the number and extent of NPRS stretches (e.g. Benejam et al., 2010; Skoulikidis et al., 2011; Datry et al., 2014a).

Table 1

Number and density of large dams in the EU-Med countries (source: ICOLD - International Commission on Large Dams, 2015).

\begin{tabular}{lll}
\hline Country & Number of large dams $(>15 \mathrm{~m})$ & Number of dams $/ 1000 \mathrm{~km}^{2}$ area \\
\hline Portugal & 217 & 2.35 \\
Spain & 1082 & 2.14 \\
France & 713 & 1.30 \\
Italy & 542 & 1.80 \\
Greece & 164 & 1.24 \\
Cyprus & 57 & 6.16 \\
EU & 7000 & 1.75
\end{tabular}

In Spain, the mean annual flow of the Ebro River has decreased by $40 \%$ during the past 50 years, mainly as a result of climate and land use changes, as well as of increased water abstraction, mainly for irrigation (Gallart and Llorens, 2004). Similarly, surface flow of the Guadiana River has sharply decreased during the past 30 years, causing the drying of headwater sections. In some areas, the groundwater table has dropped by 30-40 m (Sabater et al., 2009).

In Greece, unsustainable water resources management, together with a progressive decline in precipitation, has altered the natural flow regime of most rivers (Skoulikidis, 2009). Many farmers face serious water shortage during very dry summers (Isendahl and Schmidt, 2006). As a consequence, they construct provisional weirs along river courses for surface water abstraction, which often leads to artificial desiccation and the conversion of PRS into NPRS (e.g. Chadzichristidi et al., 1991; Economou et al., 1999; Bobori and Economidis, 2006). In the Pinios River basin intensively irrigated agriculture causes the artificial desiccation of entire river stretches during particularly dry years. In the Evrotas basin (Southern Greece), discharge has declined by $84 \%$ during the past three decades, mainly due to water overexploitation for irrigation. During very dry years, such as 2007 , up to $80 \%$ of the river network dried up completely, limiting available water for irrigation and threatening the endemic freshwater fish fauna (Skoulikidis et al., 2011).

Cyprus exhibits clear evidence of climate change, which in combination with unsustainable water management practices, has resulted in the recent transformation of PRS into NPRS. In addition, the slogan "Not a drop of water to the sea" has determined Cyprus water policy since the 1960s (Water Development Department, 2014). It impacted the flow regime of river sections downstream of dams and shifted them from intermittent to ephemeral and from ephemeral to episodic states. The impact of dams, the overexploitation of aquifers, the decrease in rainfall observed after 1970 and the reforestation of several mountainous areas have resulted in a $20-60 \%$ decrease in surface flow (Rossel, 2002). The flow of the Kouris river downstream of Kouris Dam, for example, decreased by $90 \%$ during the post-dam period, causing a deterioration of the delta as well as degradation of the ecosystem services provided by the aquifer (Tzoraki et al., 2014).

On the other hand, reservoir operation for hydropower production, which is particularly required in the summer for cooling purposes, can reverse the seasonal flow regime of impounded and fragmented rivers. Today, large dammed rivers in Greece, such as the Acheloos, Nestos and Aliakmon Rivers, exhibit high to maximum discharge in summer (Skoulikidis, 2009). In the Acheloos River, for example, 30\% of the annual runoff occurs during the summer months, compared to $11 \%$ prior to dam construction (Skoulikidis, 2002). Furthermore, WWTPs' effluents and releases from agricultural, industrial and mining operations, as well as inter-basin transfers lead to an increase in summer flow, transforming some NPRS into perennial watercourses (Hassan and Egozi, 2001).

\subsubsection{Ecological impacts}

Artificial alterations of the hydrological regime affect the health, sustainability and biodiversity of fluvial ecosystems. While native species exhibit physiological, behavioral and life-history adaptations to natural drought events (Williams, 1996; Poff et al., 1997; Gasith and Resh, 1999; Magoulick and Kobza, 2003; Matthews and Matthews, 2003), the artificial increase in the frequency and severity of water stress may be considered a disturbance to which species are evolutionarily not adapted (Bunn and Arthington, 2002; Stanley et al., 2004; Magalhães et al., 2007; Belmar et al., 2012; Datry et al., 2014b). Artificial intermittence may lead to a decline of freshwater species richness and abundances and to a loss of migratory pathways for many fish species (Larned et al., 2010). A major decline in native fish diversity has been already reported in many Iberian rivers, closely linked to unsustainable water management (Aparicio et al., 2000; Benejam et al., 2010; Clavero et al., 2010). 


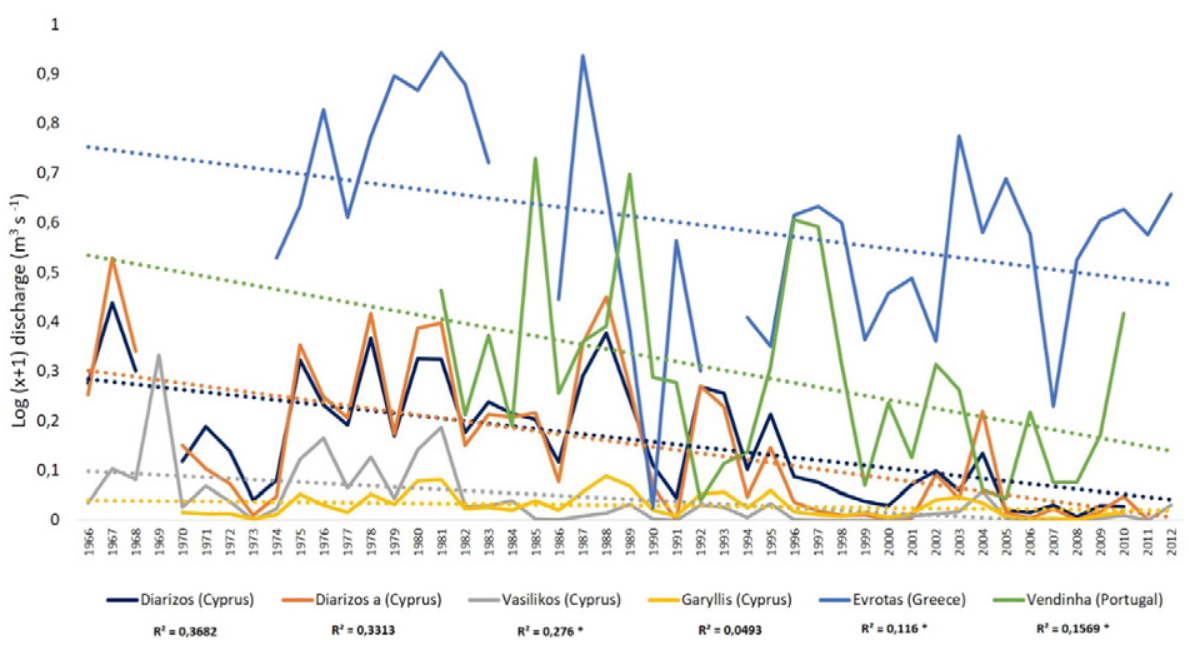

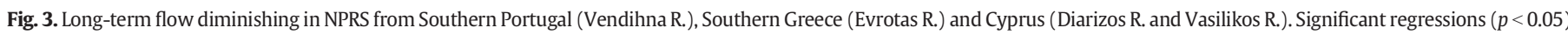
are denoted with an asterisk.

Water management infrastructures and practices alter key hydrological processes that maintain riverine habitat diversity, longitudinal, lateral and vertical connectivity gradients, and good water quality conditions (Prat and Ward, 1994; Bunn and Arthington, 2002; Pringle, 2003). The vast seasonal decline of river flow in NPRS makes them particularly sensitive to anthropogenic pressures, especially regarding water quality (Morais et al., 2009; Rosado and Morais, 2010; Rosado et al., 2012; Lopez-Doval et al., 2013). As a result, many NPRS suffer from eutrophication, hypoxia and high concentrations of industrial and agricultural contaminants (Cooper et al., 2013; Lopez-Doval et al., 2013).

Water stress and pollution may have cumulative impacts on aquatic biotic assemblages, because habitats shrink, water quality deteriorates, and predation and competition increase, as space and basic resources become even more limited (Magoulick and Kobza, 2003; Magalhães et al., 2002; Robson et al., 2011). Hence, species with low tolerance to multiple stressors are eliminated from artificial NPRS, and habitat fragmentation constrains recolonization pathways (Phillipsen and Lytle, 2013; Datry et al., 2016b). Chemical pollution derived from agricultural

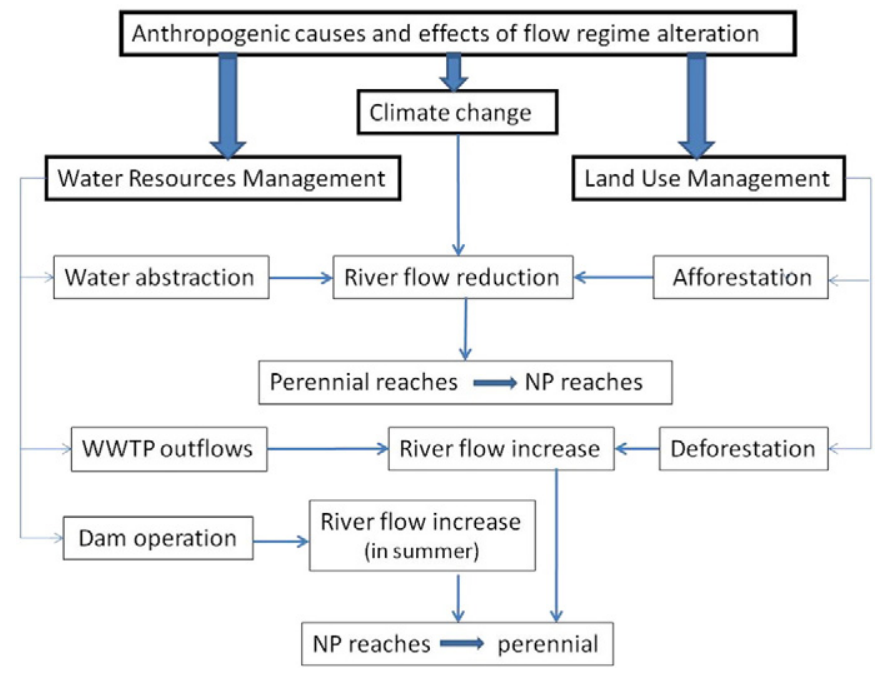

Fig. 4. Schematic presentation of the causes of flow regime alterations in the EU-Med region. Anthropogenic causes include water and land use management. Climate change is considered separately. Dam operation for hydropower production is more intense during summer than during winter due to cooling purposes, leading to an increase of summer runoff. Afforestation, contrary to deforestation, causes a decrease of surface runoff (e.g. Buendia et al., 2015) as a result of higher evapotranspiration and infiltration rates. NP: non-perennial; WWTP: Waste Water Treatment Plant. activity may have caused the observed decline of amphibian populations in NPRS (e.g. Sparling et al., 2001). At the same time, some aquatic and semi-aquatic bird species are also affected by water pollution, primarily due to declining abundances of pollution-intolerant macroinvertebrate prey (Sorace et al., 2002). Apart from pollution, NPRS are also subject to salinization. Increased salt concentrations, caused by reduced runoff and irrigation water evaporation (Cañedo-Argüelles et al., 2012, 2016), affect invertebrates, diatoms and fungal biomass as well as key ecosystem processes (Cañedo-Argüelles et al., 2014).

At the same time, knowledge about the ecological consequences of artificial perennialization remains very poor (Datry et al., 2014a). While habitat availability for lotic and lentic species increases with perennialization, habitat availability for terrestrial and semi-aquatic species declines. Although perennial flow may be sustained by effluent discharge, pollution can be detrimental for aquatic assemblages, as $\mathrm{BOD}_{5}$, dissolved oxygen, and nutrient concentrations frequently exceed the threshold of "good" water quality due to limited dilution (De Girolamo et al., 2015a). Also, in artificially sustained perrenial stream streches downstream of dams, a spread of alien fish species has been observed in many insular basins where NPSR dominate, such as in Corsica, Cyprus and Sicily among other Mediterranean islands (Blondel et al., 2010; Zogaris et al., 2012).

\section{Evolution and current state of EU-Med NPRS research and management}

\subsection{An update of research on EU-Med NPRS}

Until recently, NPRS have been considered as impoverished or even biologically-inactive ecosystems (e.g. Poff and Ward, 1989; Stanley et al., 1997; Larned et al., 2010). Therefore, we have scant information about their spatial extent (Meyer and Wallace, 2001; Benstead and Leigh, 2012; Datry et al., 2014a), hydrological regime (Acuña et al., 2014; Datry et al., 2014a) and, as they have been excluded from bioassessment programs (e.g., Hall et al., 1998; Peck et al., 2006; Acuña et al., 2014), and about their ecology (Williams, 2008; Larned et al., 2010; Datry et al., 2014a). Thus, as stated in Mazor et al. (2014), "many surveys of ambient stream conditions are incomplete, biomonitoring programs do not provide comprehensive evaluations of stream health or complete assessments of watershed or regional conditions, and watershed-management and resource-protection programs based on these assessments might be compromised".

Also at a European scale, research and management of NPRS are lagging behind, compared to other freshwater ecosystems. Reasons include the low economic value attributed to NPRS, the complexity of the 
Mediterranean biogeography coupled with political and societal issues, the poor planning of effective environmental policies, the inadequacy of legislation and its ineffective enforcement, the lack of political commitment, and the inadequate knowledge of NPRS' hydrology, ecology and biogeochemistry (Vogiatzakis et al., 2006; Acuña et al., 2014).

Limited knowledge and ineffective conservation and management of NPRS in the EU-Med are also related to the limited availability of resources for research and development (R\&D) in most EU-Med countries. The average R\&D expenditure (as percentage of Gross Domestic Product, GDP) for EU-Med countries amounts to 1.05\%, compared to an EU average value of 2.1\% (World Bank data for 2012). This imbalance is even more pronounced if one considers the relatively low average GDP per capita for the EU-Med countries (20,130 US\$) compared to the EU average (36,320 US\$, World Bank data for 2014).

During the past 15 years several EU-Med research institutions have started to consider NPRS, stimulated by a number of European projects, supporting the implementation of the WFD. Projects included AQEM (http://www.aqem.de/), STREAMES (http://www.streames.org/), STAR (http://www.eu-star.at/), INHABIT (http://www.life-inhabit.it/), REFORM (http://www.reformrivers.eu/) and MARS (http://www. mars-project.eu/). Gradually, the EC funded a number of projects that focused exclusively on NPRS, such as tempQsim (http://www. tempqsim.net/), MIRAGE (http://www.mirage-project.eu/) and more recently GLOBAQUA (http://www.globaqua-project.eu/), LIFE + TRivers (http://www.lifetrivers.eu/) and SMIRES (COST Action CA15113). The tempQsim project addressed the dynamics of NPRS and the integrated water management in semiarid Mediterranean river catchments. The MIRAGE project focused on the development of knowledge and tools required for a sound management of NPRS. Recently, the REFORM project addressed a number of important issues including hydromorphological aspects, directly or indirectly related to NPRS, in order to support adequate restoration and management activities. The current GLOBAQUA and MARS projects apply a multidisciplinary approach in order to study the interaction of multiple stressors, including water stress conditions. The specific aims are to better understand how current management practices and policies could be improved by identifying main drawbacks and developing alternative opportunities (Navarro-Ortega et al., 2015). The LIFE + TRivers project aims to create new tools in order to improve the management of NPRS, according to the WFD. Finally, SMIRES (www.smires.eu), a consortium of natural, social and economic scientists, aims at compiling and synthesizing knowledge and management practices on NPRS across all biomes in Europe, in order to produce organised data bases on hydrology, biogeochemistry and biodiversity and to provide uniform and innovative management tools at the EU scale. To date 40 researchers and 25 managers from 23 European countries are participating in this program. Furthermore, an international team of ecologists is attempting to synthesise and analyse biodiversity patterns (including plants, fish, invertebrates) across NPRS in Europe and worldwide (IRBAS, http:// irbas.cesab.org/; Datry et al., 2014a; Leigh et al., 2015a, 2015b). This research initiative aims to better understand and manage NPRS. Recently, another relevant international initiative, the 1000 NPRS project, started (http://1000_intermittent_rivers_project.irstea.fr/), involving $>120$ researchers from 32 countries (Datry et al., 2016c). The aim is to conduct synoptic sampling campaigns and experiments in hundreds of NPRS in all parts of the world, thereby advancing the understanding of fundamental biogeochemical and ecological processes in NPRS.

Simultaneously to the implementation of European research projects related to NPRS, and despite the slow progress in incorporating them into national legislation frameworks, regional and national research projects have started to better integrate NPRS into management practices and schemes; these projects are briefly presented below.

In Portugal, the Foundation for Science and Technology (FCT) supported a number of related projects. The Portuguese Environmental Agency (APA) is implementing a Program of Surveillance and Warning of Droughts that closely follows the spatiotemporal variations in precipitation. In 2001, APA started implementing a national monitoring network that includes NPRS too (SNIRH, http://www.snirh.pt/).

In Spain, several NPRS research projects were initiated in the last 15 years, such as the GUADALMED project (1998-2005) that aimed to assess the ecological status of Mediterranean rivers and streams in accordance with the WFD (Prat, 2002). More recently, the ConsoliderIngenio SCARCE project "Assessing and predicting effects on water quantity and quality in Iberian rivers caused by global change (20092014)" specifically addressed the relevance of water scarcity for water quality, water availability, the ecological status and the related services of NPRS (Navarro-Ortega et al., 2012).

In France, during the last 10 years five regional and national research programs have been conducted on NPRS. One project specifically addressed biological assemblages and physico-chemical conditions in the Rhône-Alpes Region (Datry et al., 2014b). A second project attempted to model the distribution of NPRS reaches across the national hydrological network (Datry, 2012; Snelder et al., 2013). Another program predicted the effects of climate change on flow intermittency and biodiversity in two rivers located in the Mediterranean region of France (https://r2d2-2050.cemagref.fr/). An on-going project examines the resilience of river assemblages to drying in relation to the spatial distribution of drying events across river networks (Vander Vorste et al., 2015a, 2015b). Finally, a project that is now currently running (2015-2019) explores how fragmentation by drying in headwaters alters beta diversity patterns and metacommunity dynamics of fish and invertebrates, using morphological and molecular approaches.

In Italy too, NPRS have been the focus of a number of national research projects, funded by the Italian Ministry of Research and the EU, such as MICARI, INHABIT and AQUASTRESS (FP6 IP 511231-2, 20042008 - http://www.aquastress.net/) (e.g. Amalfitano et al., 2008; De Girolamo et al., 2012; Giordano et al., 2013). Within the MICARI project (MIUR, D.M. 408 Ric. 20.03.2002 - Settore "RISORSE IDRICHE", 20032005), the concept of lentic-lotic character of rivers was developed (Buffagni et al., 2009, 2010). Later on, the INHABIT project (LIFE08 ENV/IT/000,413, 2010-2014 - www.life-inhabit.it) dealt explicitly with NPRS of Sardinia, focusing on lentic-lotic riverine habitat components, so that they can be effectively considered when classifying rivers, as well as planning and checking the effect of RBMP Program of Measures (PoMs).

In Greece, the rapid implementation of the WFD, which has lagged behind in the past, has not yet allowed state authorities to particularly focus on NPRS research and management. However, the WFD national monitoring network already includes a number of NPRS.

In Cyprus finally, NPRS research has also lagged behind due to a lack of competent research institutions. Nonetheless, due to obligations stemming from the WFD, Cyprus has progressively introduced a water status assessment based on biological quality elements such as benthic invertebrates, benthic diatoms and aquatic macrophytes (e.g., Karavokyris et al., 2011). The outcome of these assessments, coupled with a re-examination of hydrological data and classification, may advance the development of adequate management strategies.

Globally, the number of scientific publications focusing on NPRS has increased exponentially in the past 20 years; with an average of 20-25 papers published annually in the last years, half of them in the fields of biology and ecology (Datry et al., 2011). To estimate the recent research activities on EU-Med NPRS, a query was performed to compare scientific publications worldwide and at the Mediterranean basin level (Table 2).

Publications on Mediterranean temporary or intermittent rivers and streams comprise about $10 \%$ of the total number of related papers worldwide (Table 2). For ephemeral rivers and streams, the relative proportion is lower (6\%). These numbers are deemed high, considering the surface area and the population of the EU-Med region (i.e. 1.56\% and $2.97 \%$ of the total human population and area, respectively; data: http:// data.worldbank.org/), but also considering the low research expenditure of EU-Med countries compared to the world average. The majority 
Table 2

Scientific publications on NPRS globally, and the relative proportion of publications on Mediterranean NPRS.

(sources: Web of Science and ProQuest, period: 1900-2015, accessed: October 2015).

\begin{tabular}{|c|c|c|c|c|}
\hline \multirow[t]{2}{*}{ Term } & \multicolumn{2}{|l|}{ WEB OF SCIENCE } & \multicolumn{2}{|l|}{ PROQUEST } \\
\hline & $\begin{array}{l}\text { \# of publications } \\
\text { worldwide }\end{array}$ & $\%$ publications Med & \# of publications worldwide & $\%$ publications Med \\
\hline "temporary river" & 1319 & & 1564 & \\
\hline “Temporary stream” & 1128 & & 834 & \\
\hline "Mediterranean temporary river" & 126 & 9.6 & 102 & 6.5 \\
\hline "Mediterranean temporary stream" & 125 & 11.1 & 88 & 10.6 \\
\hline "Intermittent river" & 1114 & & 1336 & \\
\hline "Intermittent stream" & 1653 & & 1206 & \\
\hline "Mediterranean intermittent river" & 129 & 11.6 & 115 & 8.6 \\
\hline "Mediterranean intermittent stream" & 149 & 9.0 & 121 & 10.0 \\
\hline "Ephemeral river" & 1017 & & 1082 & \\
\hline "Ephemeral stream" & 1095 & & 873 & \\
\hline "Mediterranean ephemeral river" & 66 & 6.5 & 67 & 6.2 \\
\hline "Mediterranean ephemeral stream" & 62 & 5.7 & 52 & 6.0 \\
\hline
\end{tabular}

of publications (37\%) refer to macroinvertebrates, followed by biogeochemistry (14\%), pollution (9\%) and diatoms (5\%). Domains such as hydrology, ecology, fish, biology-other, microbiology and management are less represented (1.6-3.7\% each).

\subsection{Specific research achievements in EU-Med NPRS}

Many European and national projects advanced our knowledge about EU-Med NPRS regarding their geographical extent, pressures and impacts, hydrological character and the relationship with biotic assemblages as well as with biogeochemical and ecological processes. This increasing knowledge is facilitating the development of adequate management strategies for NPRS.

\subsubsection{Geographical distribution of NPRS}

Efforts have been made to estimate the spatial distribution and extent of NPRS at the country (Snelder et al., 2013; Mulas et al., 2009; Regione Siciliana, 2010; Fig. 2), regional (Gómez et al., 2005) and river basin scales (Skoulikidis et al., 2011; Rosado et al., 2012), though overlap in definition of intermittent, ephememeral and episodic systems is an issue.

\subsubsection{Pressures and impacts}

A fundamental research topic has been the assessment of the impacts of anthropogenic pressures on EU-Med NPRS. Pressures include agricultural land use, alien species, grazing, rubbish disposal, release of effluents, and habitat destruction such as through the use of NPRS as roads (Gómez et al., 2005; Suárez and Vidal-Abarca, 2008; Sánchez-Montoya et al., 2009). The response of various macroinvertebrate metrics to multiple stressor gradients typical for EU-Med streams, including NRPS ones, has been also studied (Munné and Prat, 2009; Sánchez-Montoya et al., 2010). Cañedo-Argüelles et al. $(2014,2016)$ investigated the impacts of secondary salinization, which reduces aquatic biodiversity and compromises the goods and services that rivers and streams provide. Recently, Suárez et al. (2016) studied the functional responses of aquatic invertebrate assemblages along two natural stress gradients, water salinity and flow intermittency, in Mediterranean streams. They indicated that functional richness and redundancy decreased with increasing salinity and flow intermittency, with salinity being the stronger environmental stressor. Wildfires, which frequently occur during periods of extended drought, pose another major risk for NPRS. Initial floods following wildfires enhance runoff and erosion rates in burned terrains, causing elevated sediment and phosphorus concentrations in receiving downstream water bodies (Blake et al., 2010). Finally, studies that focused on the relative vulnerability of PRS and NPRS to anthropogenic stress have shown that habitat changes (García-Roger et al., 2011) and agro-industrial pressures (Karaouzas et al., 2011; Karaouzas and Skoulikidis, 2011) exert severe effects on aquatic macroinvertebrates in NPRS, more severe than in comparable PRS.

\subsubsection{Hydrological processes}

Gallart et al. (2008) investigated the hydrological regimes in a set of EU-Med NPRS basins and showed that these were depended on karstic groundwater, human disturbance and winter temperatures. Later on, a method has been developed (Gallart et al., 2012) for the analysis of NPRS regimes based on the definition of six aquatic states (Hyperrheic, Eurheic, Oligorheic, Arheic, Hyporheic and Edaphic). Recently, a European stream classification method, based on flow regime, has been proposed by Bussettini et al. (2015), whereas Oueslati et al. (2015) classified hydrological regime types using stream flow data from EUNPRS. At a local scale (e.g., Pardiela River basin, Portugal), the duration of drought during a hydrological year has been quantified (Rosado et al., 2012). Also, a hydrological classification of natural flow regimes in the Segura River basin showed that NPRS are mainly restricted to the southern, lowland basin (Belmar et al., 2011). Hydrological modeling has been applied to estimate the temporal extent of desiccation in broader and local scales. For example, Kirkby et al. (2011) addressed the relative frequency of ecologically critical low flow stages in semiarid rivers across Europe. Moreover, using modeling approaches, it has been shown that entire river reaches may dry out as a result of water abstraction for agriculture (Skoulikidis et al., 2011; De Girolamo et al., 2015a). Thus, De Girolamo et al. (2015b) developed a new approach for evaluating the hydrological status of NPRS, in which the divergence between the current (impacted) and the natural flow conditions are assessed by using two hydrological indicators; the long-term annual mean number of months with flow (MF) (Arscott et al., 2010), and the six-month seasonal predictability of dry periods (SD6) (Gallart et al., 2012). A method suitable to quantify hydrological alterations in the absence of stream flow data has also been tested (De Girolamo et al., 2015b). Similarly, in order to estimate the flow regime of NPRS in the absence of flow data, Gallart et al. (2016) have proposed alternative approaches based on historical aerial photographs and on interviews.

\subsubsection{Biotic responses to flow intermittency}

Recent research has led to a better inventory and understanding of biotic assemblages in NPRS, including aquatic (Graça et al., 2004; Datry, 2012; Bonada and Resh, 2013; García-Roger et al., 2013) and terrestrial invertebrates (Corti and Datry, 2012, 2015; Sánchez-Montoya et al., 2016), diatoms (Novais et al., 2014; Barthès et al., 2014), microbial and algal assemblages (Amalfitano et al., 2008; Romani et al., 2013) as well as vertebrate assemblages, such as fish (Pires et al., 1999; Zogaris et al., 2012; Vardakas et al., 2015) and semi-aquatic carnivores (Clavero et al., 2003; Ruiz-Olmo et al., 2002, 2007). Other recent studies focused on the mechanisms allowing species to cope with recurrent drying as well as to produce quantitative relationships between drying 
duration and frequency (Datry et al., 2014b). In most cases, taxa richness of aquatic macroinvertebrates was lower in NPRS than in PRS (Muñoz, 2003; Morais et al., 2004; Sánchez-Montoya et al., 2009, 2010; Belmar et al., 2012; Datry, 2012; Datry et al., 2014b), but see Bonada et al. (2007b, 2008) and Skoulikidis et al. (2011). The seasonal community composition differed between PRS and NPRS (Bonada et al., 2008); in NPRS, invertebrates exhibiting low dissolved oxygen requirements and pool-like strategies dominate during the contracting phase (Pires et al., 2000; Acuña et al., 2005; Bonada et al., 2007b; García-Roger et al., 2013), whereas resilient taxa and species with riffle-like strategies dominate during the expansion phase (Bonada et al., 2007b; Datry et al., 2014b). Overall, collectors are more abundant in NPRS than in PRS and, in particular for NPRS, the number of predators increases in remaining pools during the contracting phase (Sabater et al., 2006; Bonada et al., 2007b).

Flow intermittency not only affects aquatic invertebrate assemblages but may also control terrestrial invertebrate assemblages in the channel and in adjacent terrestrial habitats of NRPS. Recently, Sánchez-Montoya et al. (2016), who studied two Mediterranean NRPS streams, reported that not only river drying, but also the length of the dry period, changes the composition of terrestrial arthropod assemblages, although taxonomic richness and total abundance were similar between perennial and intermittent reaches.

The hydrological disturbance of NPRS affects species richness, density, biomass, composition, and size (age) structure of fish assemblages (Benejam et al., 2010; Skoulikidis et al., 2011). Several studies have indicated significantly lower fish densities in NPRS (Mas-Martí et al., 2010), while others reported higher densities due to crowding effects (Pires et al., 1999; Skoulikidis et al., 2011). Species composition and size structure shifts are also evident in many NPRS (Mas-Martí et al., 2010; Skoulikidis et al., 2011), where the species remaining in non-perennial sites are usually small-sized tolerant species. However, harsh conditions imposed by the dry period favour many exotic species, due to their preference for limnophilic conditions (Vila-Gispert et al., 2002). Species such as mosquitofish, pumpkinseed sunfish and common carp are well-known examples of exotic species common in many EU-Med countries, mainly as a consequence of the large number of reservoirs.

Regarding benthic diatom assemblages, Tornés and Ruhí (2013) found that species in NPRS were less nested and more generalist than those in PRS. Barthès et al. (2014) observed a significant and long-lasting impact of even short-term drought events on diatom assemblage structure. On the contrary, Novais et al. (2014) found that diatom richness increased with flow intermittency.

There are only a few studies on vertebrates in EU-Med NPRS. These have shown that desiccation influences the availability of prey such as fish, which again may strongly affect the European otter (Lutra lutra) (Clavero et al., 2003; Ruiz-Olmo and Jiménez, 2009). Consequently, the mortality rate of otters increases, their abundance diminishes, and breeding success declines (e.g., Ruiz-Olmo et al., 2001). Furthermore, due to summer droughts, the breeding time of otters occurs earlier in Mediterranean than in temperate streams (Ruiz-Olmo et al., 2002).

The species composition of the riparian vegetation is also determined by flow intermittency. Bruno et al. (2014), for example, detected that drought duration is one of the most important environmental determinants of the composition and variation of the herbaceous and woody riparian vegetation in the Segura river basin (Southeastern Spain). Drought duration leads to a reduction in functional redundancy and thereby decreases ecosystem resistance and resilience to future disturbances (Bruno et al., 2016).

\subsubsection{Hydromorphology vs ecological quality}

The relationship between hydrology and ecological or integrity in NPRS has been frequently explored in various studies that showed that the ecological status depends on the alteration of flow-related natural components (e.g. Coimbra et al., 1996; Buffagni et al., 2009, 2010).
Water abstraction, for example, favours lentic habitat conditions, thereby affecting the structure and traits of aquatic assemblages (Buffagni et al., 2010; García-Roger et al., 2013). Gallart et al. (2012) developed a new approach to analyse the regime types of NPRS in relation to their controls on the composition and structure of aquatic biota. Prat et al. (2014) developed an integrated assessment strategy for NPRS (i.e. the MIRAGE tool-box). Based on the aforementioned aquatic states, the MIRAGE tool-box entails a series of methodologies for determining and analysing NPRS' aquatic regimes, and for relating the ecological and chemical status to their specific hydrological status. Similarly, Cid et al. (2016) developed a biological tool (BioASTool) to assess flow connectivity in NPRS reference systems based on benthic invertebrates. This tool can also be applied when hydrological data are missing, using the taxonomic and biological trait composition of the macroinvertebrate community as predictors. Likewise, Buffagni et al. (2010) stressed that the lentic-lotic character of rivers (e.g. quantified by proxies such as the Lentic-lotic River Descriptor (LRD) score system, see Buffagni et al., 2009) has to be taken into account when assessing their ecological status.

Regarding morphological modifications of river channels and river banks, it has been demonstrated that their impact on Sardinian NPRS is well detected by the benthic metrics (Buffagni et al., 2016) that are commonly used for monitoring PRS and NPRS. In the absence of water pollution and/or water abstraction, the large majority of stream reaches that showed evident morphological alteration were correctly classified as medium to low ecological status (Buffagni et al., 2016). Therefore, even if the influence of the highly variable hydrological regime of NPRS on benthic assemblages is undeniable, effects subtler than those of pollution, such as morphological modifications, can be detected and quantified.

\subsubsection{Biogeochemical processes}

NPRS are recognized as biogeochemical reactors (Larned et al., 2010), and alternating wetting and drying cycles create biogeochemical hot spots and hot moments (McClain et al., 2003). Mineralisation, demineralisation, nitrification, denitrification, and nitrate reduction are among the processes that prevail during desiccation and rewetting (Peterjohn and Schlessinger, 1991; Mummey et al., 1994; McDonough et al., 2011).

Dry watercourses may cause substantial $\mathrm{CO}_{2}$ emissions, higher than running or stagnant waters, which demonstrates the importance of NPRS for the global carbon cycle (Von Schiller et al., 2014; Gómez-Gener et al., 2016). In NPRS, coarse particulate organic matter (CPOM) accumulates in standing pools and at the surface of dry habitats, and as the river dries, the primary agents of CPOM decomposition shift from leaching and processing by aquatic micro-organisms and invertebrates to photo-degradation by UV and processing by terrestrial micro-organisms and invertebrates (Corti et al., 2011; Dieter et al., 2011). The decomposition rate decreases according to drying duration and the progressive disappearance and inactivity of aquatic fungi and shredders (e.g. Corti et al., 2011; Datry et al., 2011; Foulquier et al., 2015). In dry habitats, the decomposition rate is reduced to almost zero due to the low abundance of terrestrial shredders, low microbial activity and absence of mechanical breakdown (Corti et al., 2011). Experimental desiccation in microcosms with sediments from different EU-Med NPRS revealed a prompt decline of the initial bacterial carbon production during desiccation, while complete desiccation led to a delay in mineralization processes and synthesis of new biomass (Amalfitano et al., 2008). These studies led to a better understanding of how the tempos, rates and timing of organic matter processing differ between PRS and NPRS (Datry et al., 2014a). Other studies focused on stream metabolism by continuous oxygen measurements (Acuña et al., 2004; Izagirre et al., 2008). Regarding the nutrient processes, von Schiller et al. (2011) stressed that hypoxic conditions in disconnected pools can cause rapid ammonium and phosphate release from sediments. Along gradients with increasing fragmentation, a decrease of 
nitrate accompanied by an increase in ammonium has been attributed to both assimilation and heterotrophic activity, such as reduction of nitrate to ammonia and/or denitrification (Skoulikidis et al., 2017). Microcosm experiments showed that drying increased the sediment nitrate content (Arce et al., 2014) and that in the initial stages of desiccation, $\mathrm{N}$-mineralization and nitrification were stimulated (Tzoraki et al., 2007; Gómez et al., 2012). Opposite trends in nitrogen processes are probably related to hydrological and sediment moisture factors.

The decomposition of organic matter (Corti and Datry, 2012; Rosado et al., 2014) and its effects on nutrient variability during rewetting have been also researched. Skoulikidis and Amaxidis (2009) and Ramos et al. (2015) showed that annual nutrient concentrations and cycles, as well as sediment transport during initial autumn floods were very dynamic and extremely variable in space and time. This indicates the importance of initial floods on water quality issues, particularly for nutrients. Upon rewetting, rapid mineralization of organic matter and subsequent nitrification controlled $\mathrm{N}$ species in river water (Skoulikidis and Amaxidis, 2009; Skoulikidis et al., 2017). Arce et al. (2015) conducted microcosm experiments which provided evidence that during rewetting of dry sediments, nitrate, favoured by anoxic conditions, can be rapidly denitrified, suggesting an improvement of water quality in polluted streams. To simulate the time response of NPR reaches on geochemical and hydrologic mass balances, Tzoraki and Nikolaidis (2007) developed a biogeochemical model. Finally, the crucial role of biofilm in recovering ecosystem functions upon flow resumption has been also revealed (Timoner, 2014; Timoner et al., 2014a, 2014b, 2014c).

\subsection{Management in EU-Med NPRS}

As a result of the inadequate involvement of EU-Med countries in the development of the EU's Water Framework Directive 2000/60/EC (WFD), coupled with a general undervaluation of NPRS systems, the WFD does not specifically address NPRS (Nikolaidis et al., 2013). This gap created several issues related to their typology, to ecological assessment indices, as well as to minimum flow requirements and other protection measures to be incorporated in RBMPs.

\subsubsection{Typology}

In the framework of the application of the intercalibration (IC) exercise (European Commission, 2013), the EC recognized the need to include NPRS (RM-5 type) in the common Mediterranean intercalibration types. On this regard, data from RM-5 rivers on macroinvertebrates and diatoms were successfully intercalibrated for five Mediterranean countries (e.g. Feio et al., 2014a). The RM-5 IC type judged from its description of simply "temporary streams" (European Commission, 2013) is an 'umbrella' category designed to embrace all of the NPRS present in Europe. In line with the whole IC process, this helped results to be plainly understood and agreed, ready to be transferred at Member State (MS) scale to all national types corresponding to NPRS. However, it must be noted that datasets selected for WFD IC often refer to well-defined national types, i.e. normally a single type out of the whole range of types and conditions, for which data availability is at least satisfactory (e.g. Erba et al., 2009; Feio et al., 2014b). Hence, because the datasets used were from specific NPRS river types only, the transferability to all Mediterranean NPRS, as suggested by the description of the type as "temporary streams", is doubtful and it is unsure with respect to ephemeral streams. From this it follows that MS had/ have to go into more depth on hydrology-related issues, so that NPRS types finally adopted are hydrologically well defined and, as a result, ecologically sound.

At a national scale, since institutions in the EU-Med countries have traditionally focused on monitoring PRS, the approaches, methods and relevant data to quantify, locate and classify NPRS are often missing. In addition, according to the WFD, a NPRS may not be considered a water body, and therefore may not be protected, depending on the typology applied and the water body classification method adopted in a particular region (Munné and Prat, 2004). Up to recently, the different criteria used in each river basin have fostered a patchy implementation of the WFD throughout Europe, which has resulted in the recognition of $\mathrm{NP}$ waterways in only a few river basin districts in the EU (Acuña et al., 2014). In France, for example, NPRS have been initially classified as "atypical" in the environmental flow legislation (Decret, 2007) thus, no minimum flow management plans are required for these systems. Even in Spain, with a much longer tradition in studying NPRS than in other EU-Med countries, a national hydrological classification is still missing (Belmar et al., 2011). According to the Spanish water legislation (“Instrucción de Planificación Hidrológica”, ORDEN ARM/2656/2008), 12 out of 32 WFD-ecotypes are termed as Mediterranean ecotypes, but none of them specifically addresses NPRS. In addition, many NPRS are potentially excluded from the assessment of the ecological status, as only rivers with natural flows $>0.1 \mathrm{~m}^{3}$ and catchment areas $>10 \mathrm{~km}^{2}$ are required to be assessed (i.e. are considered as "water bodies"). To solve these problems, LIFE + TRivers project in Spain aims to provide Water Agencies with methodologies to adequate include NPRS in the RBMPs. Italy formally included NPRS in standard monitoring programs since the adoption of an official typology for the WFD, but the WFD has primarily been implemented for catchments larger than $10 \mathrm{~km}^{2}$ (MATTM, 2008), thus ignoring a large number of NPRS. The separation of NPRS from perennial ones was set as the first key factor in the Italian river typology (Buffagni et al., 2006) to emphasize their distinctiveness and the need for incorporating hydrological information. Three major categories of NP streams are recognized, being divided by the observed/expected number of dry months per year: 'intermittent' (water $>8$ months), 'ephemeral' (water $<8$ months) and 'episodic' (water only present after intense precipitation events). Eventually, four NPRS types are recognized for the aims of WFD monitoring, with episodic streams being excluded. In all Italian regions where they are present, the routine monitoring of such types is bringing a rapid growth in data availability and sharper focus on management options. In Greece, the 1st River Basin Management Plans (RBMPs) refer to rivers and streams with a Strahler of class 4 and higher (EC, 2015), thus ignoring a vast number of headwater NPRS. For the 2nd RBMPs, Greece is applying the RM-5 typology which includes two subcategories; natural or artificial intermittent and ephemeral rivers and streams. As intermittent are termed rivers and streams that cease to flow for weeks or months, whereas as ephemeral are considered streams with a hydroperiod ranging from days to several weeks. In Cyprus, with few PRS, NPRS stream flow data covering the whole gradient from perennial to episodic rivers does exist. However, the spatial distribution of the different flow regime types has been quantified only very recently (Dörflinger in ENVECO S.A. and I.A.CO Ltd., 2013). Still, only catchments with an area $\geq 10 \mathrm{~km}^{2}$ were considered and 1 st order streams were not taken into account. In the 1st River Basin Management Plan of Cyprus, perennial and non-perennial river types had been distinguished already (Karavokyris and Partners Consulting Engineers S.A. and Kaimaki, 2011). However, further distinction between streams with intermittent and ephemeral flow regime was not done and this hampered proper biological assessment. Therefore, the Temporary Stream Regime Tool (TSR-Tool) described by Gallart et al. (2012) was adopted as basis for the new stream typology and thus the principle of flow continuity is introduced in the 2nd River Basin Management Plan (Ministry of Agriculture, Natural Resources and Environment, 2011). The new typology consists of four types, three of which are NPRS, and there are separate types for intermittent and ephemeral flow regimes. However, most ephemeral streams are proposed to not be considered as water bodies any more, in comparison with the 1st RBMP. Nevertheless, it is proposed to monitor water and sediments of ephemeral streams and to publish annual reports with the results.

\subsubsection{Ecological classification}

For the assessment of aquatic macrophytes, Papastergiadou and Manolaki (2012) have developed the dedicated MMI index for Cyprus' 
R-M5 type streams. Specific macroinvertebrate indices, such as the Iberian Mediterranean Multimetric Index (IBMWP: Alba-Tercedor et al., 2002), the multimetric IM9 for Portuguese rivers (Pinto et al., 2004) and the STAR ICMi index (Buffagni et al., 2006b), which is applied in Italy, Greece and Cyprus, have been developed to support the implementation of the WFD. However, these indexes depend on the hydrological period (wet and dry), and therefore hydrological characteristics should be considered in order to calculate reference conditions for each period (Buffagni et al., 2009; Munné and Prat, 2009). If the hydrological period is not considered, metrics such as IASPT or the IMMi-L could be more appropriate because they are less sensitive to hydrological variations (Munné and Prat, 2009; 2011; Sánchez-Montoya et al., 2010). Furthermore, methodologies to guide managers on the timing of macroinvertebrate sampling for the purpose of assessing the ecological status have been also developed (Prat et al., 2014). For example, when NPRS monitoring is applied during the flowing phase, standard ecological assessment methods for perennial streams may be used (Prat et al., 2014). One example is the IPS index (Cemagref, 1982) which is the intercalibration index for the assessment of phytobenthos in R-M5 rivers of Cyprus, Portugal and Spain (European Commission, 2013). Also, a combination of selected metrics and associated thresholds were proposed in order to assess the aquatic state in reference NPRS, especially in the absence of hydrological data (Cid et al., 2016). However, to sample NPRS only in suitable time periods (Prat et al., 2014) raises problems for routine monitoring programs, since in many cases hydrological information is missing. Even when long-term hydrographs are available, it is almost impossible to predict the hydrological regime of these systems so that planning of appropriate sampling timing becomes unrealistic. In Italy, guidelines were provided on how to manage sampling of e.g. aquatic macroinvertebrates in NPRS (Buffagni and Erba, 2014). Since the possibility to forecast hydrological conditions is limited, complementary approaches were proposed to correct reference conditions, based on the actual habitat conditions in the period when sampling was performed (Buffagni et al., 2009). The exceptions to this are intermittent rivers with a temporally stable wet period as is the case of several streams in Cyprus. Still, even in these streams the short period of suitable flow makes the implementation of routine monitoring programs difficult. It should be also taken into account that the large majority of existing metrics refer to intermittent rivers thus indicating the lack of methods for the ecological classification of ephemeral streams. Realistically, the potential adoption of new biological metrics dedicated to NPRS will supplement the existing systems by providing correction factors in classification.

\subsubsection{Establishment of ecological flows and RBMPs}

The EU-Med countries, acknowledging the adverse effects of inadequate water management on lotic ecosystems, started incorporating ecological flow requirements into their national legislation. However, minimum flow requirements and hydropeaking issues have been only partly incorporated in previous RBMPs by the Member States (Benitez and Schmidt, 2012). In Portugal, the Ordinance 1450/2007 made mandatory a study defining an ecological flow regime downstream of dams, and Law No $7 / 2008$, although not yet implemented, states that the owner must sustain a flow regime adapted to fish life cycles, with the aim of maintaining ecosystem integrity (European Commission, 2015). In addition, the management and conservation of a NPR basin (Pardiela) has been addressed (Rosado et al., 2012). The Spanish Water Law (RDL 1/2001, L11/2005) imposes environmental flows for the conservation of fish assemblages and riparian vegetation. Ecological flow requirements were defined for over 400 water bodies, based on hydrological and hydrobiological methods for target species (EEA, 2012). In France, regulation of water abstraction is implemented in the RBMs in basins with quantitative water deficits, to ensure the good functioning of aquatic ecosystems (European Commission, 2015). Environmental flows are also prescribed in the Italian national legislation. As a general rule, at least $10 \%$ of the natural flow (yearly average with possible adjustments for specific months and conditions) should be preserved, but often this can be reduced to $5 \%$, or in justified cases can reach a status of complete surface desiccation. It is the responsibility of the individual River Basin Authority to set up specific rules for rivers under their jurisdiction, and in some cases this may lead to more protective flow rates. In 2016, in the 1st Plan review and update (2nd cycle planning River Basin Management Plan 2015-2021) of the "Appennino Meridionale District”, the Apulia Region fixed ecological flow requirements specific for NPRS, based on hydrological criteria. It has been established that e-flow has to vary through the year following the natural flow regime and it can be zero during the natural dry period, as it cannot be higher than natural streamflow. More in general, a recently established working group chaired by the Italian Ministry of Environment is currently drafting e-flows criteria to be transferred into a national legislative decree, which will cover NPRS too. Similarly, in Greece, a provisional law (Greek Official Gazette 2464/03.12.2008) defines a minimum ecological flow requirements based on hydrological criteria and a preliminary RBMP has been developed (Evrotas River basin, Greece; see Nikolaidis et al., 2009; Vardakas et al., 2009; Demetropoulou et al., 2010). In Cyprus, the Integrated Water Management Law (N.79(I)/2010) provides guidelines to impose ecological flows. The Cyprus River Basin Management Plan (RBMP) includes minimum flow thresholds for all major dams (Karavokyris et al., 2011).

In the course of the WFD implementation, technical reports (ETC/ ICM Technical Report 2/2012, EEA, 2012) indicated that habitat and hydromorphological alterations are affecting almost $40 \%$ of river water bodies in Europe, preventing them from reaching good ecological status. In an effort to balance water allocation between human water needs and aquatic ecosystems, the European Commission provided ecological flows (e-flows) CIS Guidance (European Commission, 2015) to facilitate the achievement of the WFD environmental objectives, ecosystem functionality, and a sustainable use of the European water resources. In this document, e-flows are considered within the context of the WFD as "a hydrological regime consistent with the achievement of the environmental objectives of the WFD in natural surface water bodies as mentioned in Article 4(1)". Thus, in cases where hydrological alterations are likely to prevent the achievement of the WFD environmental objectives, an assessment of the gap between the current flow regime and the e-flows should be conducted. This is particularly important for artificial NP water bodies where, if good status is not achieved, the restoration of an appropriate, near-natural flow regime, should be ensured by the PoMs within the RBMPs. It is thus expected that national legislations on ecological-flows will be modified accordingly.

Specific measures for the efficient management and conservation of NPRS ecosystems, include, among others, the restoration of flow regimes for fragmented and artificially dry ones. To maintain their ecological integrity the protection of refugia is essential (Pires et al., 1999; Magoulick and Kobza, 2003). Riparian reforestation (Tzoraki et al., 2014) and the increase of the quality and quantity of tree-related habitats (Buffagni et al., 2016) are measures related to habitat conservation and pollution abatement during flood events. The application of floating islands may be a technically and economically efficient method to decrease pollution, particularly during low flow periods (Pavlineri et al., 2017).

However, with the exception of France, specific management and conservation measures have not been yet applied for EU-Med NPRS. In the existing Spanish RBMPs, NPRS have not been included. Nevertheless, some water agencies, such as the Júcar and the Catalan Water Agency may benefit from their involvement in the TRivers project for their future RBMPs. In Italy, the 1st RBMP and its review and update identified a number of basic and supplementary measures to restore river ecosystems and achieve the environmental objectives. Several pilot projects focusing on water resources protection, habitat restoration, and monitoring were sponsored and supported. However, the measures, as well as the pilot projects, are not specifically oriented to NPRS. Also in Greece the 1st RBMP does not include any measures 
particularly targeting NPRS, since the latter have not been considered as a separate river type. The 2nd RBMP however may consider flow restoration measures for artificially dry rivers and streams. Finally, in the Draft of the 2nd Cyprus RBMP (LDK Consultants S.A. and Ecos Consulting S.A., 2015), environmental flows targeted at reaches of NPRS of special ecological importance are foreseen.

\section{Future perspectives}

\subsection{Basic research priorities}

4.1.1. Hydrological research needs (estimation and restoration of natural flow regimes)

The general lack of long-term hydrological data impedes reconstructing the "natural" flow regime of NPRS, as well as defining environmental flow regime requirements (e.g. European Commission, 2015), and developing adequate flow restoration measures to maintain/restore a good ecological status. Hydrological models have limitations due to the highly unpredictable flow regime and the karstic character of many NPRS in the EU-Med, the complex interactions with and among anthropogenic pressures, and the lack of information on the physiographic and environmental conditions of many catchments (Singh and Woolhiser, 2002; De Girolamo et al., 2015b). Indeed, a common methodology to define the "natural" flow regime, in the absence of historical hydrological data, is still missing. This is further complicated by major knowledge and information gaps, notably on water abstraction for agriculture (WWF, 2003; Wriedt et al., 2009). In countries such as Greece and Spain, the reported data on water abstraction most probably underestimate the water uses for agriculture, mainly due to a high percentage of illegal and unrecorded abstractions. In Spain, for example, it is estimated that agriculture abstracts about $45 \%$ more water than officially reported (Wriedt et al., 2009), whereas in Greece, the scale of Illegal water abstraction is believed to be enormous and impossible to estimate under the current organisational status. Therefore, the EU-Med state authorities must put much more effort into monitoring flow conditions and groundwater levels, and into calculating the relative proportion of water resources that are abstracted for irrigation and other uses. In the case of NPRS, modeling approaches cannot substitute for real data gathering.

\subsubsection{Biological research challenges}

4.1.2.1. Diversity, metapopulation and metacommunity dynamics. Up to now, most NPRS research has focused on the differences in taxonomic and functional diversity between PRS and NPRS in the EU-Med countries. Less information is, however, available on the genetic diversity and structure of populations and assemblages in NPRS (but see Múrria et al., 2010). Moreover, most population and community-ecology studies in NPRS have focused on lotic habitats. Understanding the underlying mechanisms of drying effects on metapopulation and metacommunity dynamics remains also a major challenge (see Múrria et al., 2010; Datry et al., 2016a), though it is critical for conservation and restoration planning. Furthermore, thorough analyses of the ecological consequences of artificial river drying on biodiversity require a distinct aquatic-terrestrial perspective, both in space and time (Datry et al., 2014a). Moreover, it remains unclear if assemblages from natural and artificial NPRs are similar during flowing and non-flowing phases. Finally, we know very little about the importance of the dry phase for terrestrial organisms, despite commendable ongoing research efforts.

4.1.2.2. Seasonal dynamics of biotic assemblages. Limited information exists on the seasonal dynamics (including flood events) of invertebrate and fish assemblages in Mediterranean NPRS (Hershkovitz and Gasith, 2013), due to the lack of adequate data. Hence, research on the natural variation of these assemblages during the different water phases of the NPRS, as well as on habitat availability at various time scales, is urgently needed (Robson et al., 2005). This will allow re-defining representative reference conditions and metrics for the ecological classification of NPRS.

4.1.2.3. Environmental requirements of biota. Natural drying and rewetting cycles may enhance the resilience and adaptation of populations to future environmental changes (Datry et al., 2014a). However, a further increase in artificial desiccation, in combination with a deterioration in water quality and habitat conditions, makes imperative the research on species-specific environmental linkages, feedbacks and thresholds, such as flow requirements, temperature and salinity preferences, as well as on dispersal limitations of aquatic and terrestrial biota (Hershkovitz and Gasith, 2013; Datry et al., 2014b).

4.1.2.4. Dry phase (dry river beds) and bioassessments. Despite recent progress in understanding the role of dry channels as important habitats for terrestrial arthropods (e.g. Wishart, 2000; Larned et al., 2007; Steward et al., 2011; Steward et al., 2012; Corti and Datry, 2015; Corti et al., 2013; Corti and Datry, 2014), the terrestrial phase is not yet integrated into bioassessment strategies. We also need to consider the entire hydrological cycle in order to allow a more comprehensive assessment of the ecological status of Mediterranean NPRS (Prat et al., 2014). The role of a dry river bed as a movement and dispersal corridor for terrestrial vertebrates has only recently been explored (SánchezMontoya et al., 2016). At the same time, the role of microbial assemblages during the dry phase has been studied more recently (Timoner, 2014; Timoner et al., 2014a, 2014b, 2014c), and has shown their relevant resistance to drying and resilience to flow return of these assemblages. A major environmental tipping point is when PRS turn into NPRS; therefore, we need to identify the areas that are most sensitive to shifting from one environmental state to an alternate state (i.e. early warning assessment).

\subsubsection{Biogeochemical research needs}

Understanding the role of intermittent rivers in catchment-, regional-, and global-scale biogeochemical cycles requires identifying the singularities of biogeochemical processes in NPRS. Organic matter and nutrient storage and transfer rates may be higher in NPRS compared to PRS due to their pulsed nature (Datry et al., 2014a), while in situ transformation rates may be more important in PRS. Therefore, we need to consider the spatial and temporal linkages of perennial and non-perennial sections and periods within whole river networks. Even small changes in the hydrological regime may turn a system from a source to a sink, and vice versa, for nutrients and organic carbon. However, relevant empirical evidence is still lacking.

The drought-induced hydrological disconnection in NPRS entails a distinct spatiotemporal heterogeneity along watercourses, which translates into very different sources of dissolved organic matter, potentially to be respired by the biota (Casas-Ruiz et al., 2016). Microbes in dry stream beds exhibit a higher respiration capacity than those in flowing channels, and reach similar microbial activity rates than in upland soils (GómezGener et al., 2016). The biogeochemical understanding of dry channels is still at its infancy, and much more effort is needed to quantify their relevance at the catchment and network scale. Furthermore, the ecological and societal consequences of major organic and nutrient pulses from NPRS during first flood events remain mostly unexplored (Bernal et al., 2013). Also the impact of first pulses on the transport and retention of priority substances and specific pollutants remains unknown (Dahm et al., 2016).

Future research should take advantage of the achievements in hydrology, aquatic biogeochemistry and advanced sensor and information technologies, to focus on in-situ monitoring and on targeted field and mesocosm experiments. This should include surface/groundwater interactions, as well as $\mathrm{C}, \mathrm{N}$ and $\mathrm{P}$ metabolism and interactions at the water/sediment interface. Moreover, the cause/effect relationships between pressures and biogeochemical processes on the one hand, and biotic impacts on the other, are still unexplored. Thus, targeted 
experiments are required that can contribute to unravel short-term variability and "tipping points" of biogeochemical and ecological processes during the desiccation phase and during flush flood events, as well as to explore their effects on water quality and biota. Understanding these processes may help quantifying particular pressures causing ecosystem degradation, and thus contributing to the application of appropriate measures to maintain/restore the remaining near-natural NPRS.

\subsection{Applied research priorities}

\subsubsection{Definition and mapping}

We do not know yet the detailed numbers, location, areal extent and length of NPRS in the EU-Med area. Also definitions on the boundaries of intermittent, ephemeral and episodic rivers and streams still remain vague. Thus, the classification and surveying mechanisms must be refined, validated and standardized. "Dotted lines" on topographic maps are spatially inaccurate, and therefore unreliable in efforts to locate and estimate numbers of NPRS. Moreover, EU-Med MS still have different perceptions on how to define NPRS; EU-Med countries use different topographic mapping resolutions, which lead to very different estimations of the total number and length of streams (McDonough et al., 2011). Hence, many NPRS are excluded from assessments. It is obvious that a Europe-wide definition and comprehensive classification of NPRS is urgently required, as well as a common mapping and registration strategy for the EU-Med basins, taking into consideration local variations. Since NRPS are often considered as possessing no economic value, it is unlikely that managers are going to install flow gauging stations in these catchments; thus, mapping of NPRS could be, alternatively, achieved through citizen-science projects. In some regions of France, for example, fisher associations are mapping flow states across $>3500 \mathrm{~km}$ of river networks, by means of visual observation (Datry et al., 2016b). Such efforts could be applied at the European scale, currently one of the goals of the Cost Action SMIRES.

\subsubsection{Monitoring}

Pronounced hydrological variations of NPRS cause pulsed biogeochemical and ecological processes that translate into short-term alterations in ecosystem structures and functions. Thus, hydrological and ecological monitoring schemes must consider and adapt to this variation, in order to capture short-term changes in hydromorphological, ecological and biogeochemical processes, and to understand water quality and biotic response variations.

\subsubsection{Typological classification}

The typological approach of Mediterranean rivers, especially of NPRS, is inadequate, and improperly incorporated into the RBMPs. Since, flow-gauging monitoring programs have generally ignored NPRS, hydrological information is generally missing (Acuña et al., 2014; Datry et al., 2014a). We thus lack the data required for assessing hydrological regimes and quantifying zero-flow days, in order to define the hydrological type of a given NPRS. A more dynamic typology, compared to the existing ones, coupled with advanced hydrological monitoring techniques, should be developed, considering hydromorphological changes along the river continuum, seasonal and inter-annual variability, as well as biological responses. When a river typology has to be compatible with biology, e.g. for WFD monitoring and classification, habitat variability and expected biological conditions should be defined after identifying the actual habitat conditions experienced by biota (e.g. Buffagni et al., 2009).

4.2.4. Development of appropriate metrics for ecological status assessment

High biological variability due to high hydrological instability of NPRS, in particular under climate change conditions (e.g. Bonada and Resh, 2013), pose a challenge in devising suitable approaches to assess ecological status. The cumulative effects of hydrologic variability, antecedent hydrologic conditions and drought events on biological assessment systems currently used, are largely unknown. Setting reference conditions, that may vary seasonally, can be problematic (Feio et al., 2014b; Cid et al., 2016), while classifying ecological status in periods close to the dry season is also an issue, as biological assemblages can show quite different attributes compared to those during other flow periods (García-Roger et al., 2013). In this latter circumstance, an increase in lentic conditions is often associated with a decrease in the value of the metrics normally applied, possibly causing a serious underestimation of the ecological status. In altered water bodies, these hydrology-related factors often mask pollution, water abstraction and morphological alteration, and make it arduous to disentangle the effects of different pressures on benthic assemblages. As aforementioned, to sample NPRS only in suitable time periods (Prat et al., 2014) is problematic for routine monitoring programs, since it is almost impossible to predict the hydrological regime of these systems. Thus, additional approaches should be developed to assess the ecological status of NPRS.

A first step towards a successful and cost-effective ecological status appraisal in NPRS would be to test the performance of existing classification systems and, if necessary, refine them. Furthermore, in order to better understand the differences in biotic assemblages between PRS and NPRS and to develop appropriate metrics for NPRS, future research should consider rivers and streams with similar typological and habitat characteristics. Moreover, special focus has to be placed on detecting effects other than those of pollution only, identifying the contribution of specific causes and pressures in shaping NPRS assemblages (e.g. Buffagni et al., 2016). Also, the ranking of the potential influence of different pressures and the definition of the breadth of biological response gradients are major issues of recent research activities (Gallart et al., 2012; Prat et al., 2014). New approaches and metrics, or alternatively dedicated refinements of existing classification systems, are required for NPRS, while reviews of specific methodological aspects would be also highly valuable. In fact, though there were some recent initiatives to improve the effectiveness of ecological status assessment in NPRS (e.g. Prat et al., 2014; Cid et al., 2016), more efforts are required in order to allow application in ephemeral/episodic streams too (Argyroudi et al., 2009; Nikolaidis et al., 2013). Finally, data use on physico-chemical elements and related classification systems for NPRS has to be revised, since biogeochemical cycles may differ between NPRS and PRS, and organic matter dynamics may vary more distinctly in NPRS than in PRS (Datry et al., 2014a).

\subsection{Conclusions}

The current paper reviews the state-of-the-art of research and management efforts, achievements and gaps regarding EU-Med NPRS, and proposes future research and management priorities. Major research activities during the last 15 years have considerably improved our understanding of the various structural and functional aspects of NPRS. However, NPRS still remain one of the least known aquatic ecosystems globally. The Greek philosopher Heraclitus (c. 535-c. 475 BCE) stated "Everything flows and nothing abides" and "Ever-newer waters flow on those who step into the same rivers" emphasizing the perpetual flux of all things. These famous aphorisms apply particularly to EUMed NPRS, which are characterized by complex and highly unstable functions, driven by dynamic and often unpredictable hydro-meteorological and biogeochemical and ecological processes, further augmented by human pressures and climate change.

NPRS are particularly vulnerable, because, despite some efforts to that direction, they still lack adequate legislative and policy protection, as well as appropriate management practices, especially witihin the frame of RBMPs; indeed, within the EU-Med RBMPs developed up to date, not all types of NPRS are included, while specific management and conservation measures have not been yet applied though relevant measures, such as flow restoration, have been identified in some more recent RBMPs. It is thus vital to improve the legislative framework and implement effective measures concerning appropriate monitoring, sustainable management, as well as conservation and protection of EU- 
Med NPRS. Efficient management however, requires a better understanding of NPRS structural and functional attributes. For that purpose, targeted interdisciplinary research is required. Therefore, a close cooperation among research groups actively involved in various disciplines related to the study of NPRS, such as hydro(geo)logy, hydrobiology, biogeochemistry, ecology, and advanced monitoring technologies, is urgently needed. The incorporation of social scientists and economists will be also very fruitful in order to highlight the value of NPRS to society from an ecosystem service point-of-view. Recent initiatives, such as the SMIRES COST Action, may contribute to setting and implementing such research and management priorities.

As our scientific understanding of NPRS is increasing, the importance of including them in policy and management decisions of the EU-Med states will be highly recognized. In fact, the translation of scientific work to legislation in management and protection is crucial. Within this frame, the MIRAGE project recommended specific additions to WFD (Articles 2, 4, 5 and 11), by addressing the particular characteristics of NPRS, ultimately aiming to their efficient management and protection. At the regional scale, the "Instrucción de Planificación Hidrológica", in Spain, includes guidelines for water management, following the WFD and the indices proposed to evaluate the ecological status of Spanish rivers, mostly based on the work produced within the GUADALMED project. In addition, the LIFE + Trivers project can provide useful information for managing NPRS in the EU-Med countries.

Currently, NPRS are increasingly beeing embeded in the national RBMPs. The incorporation of the e-flows CIS Guidance (European Comission, 2015) in forthcoming RBMPs, as well as the deterioration principle of the European Court of Justice (ECJ), may further promote efforts for NPRS protection by securing the restoration of flow regimes. However, in order to better integrate NPRS in forthcoming RBMPs and apply appropriate management and conservation measures, a close cooperation between scientists, EU and national policy makers, as well as local management authorities is urgently required.

Concurrently to the implementation of specific conservation measures, there is an urgent need to define economic alternatives to existing practices in irrigated farming at an EU-Med scale, in order to reduce overall water consumption, in particular during the ecologically most sensitive periods. This must coincide with the development of modern planning instruments, more effective land use policies and the linking of the current Common Agricultural Policy to the Horizon 2020 strategy (Nikolaidis et al., 2013).

\section{Acknowledgments}

Part of the work was conducted within the framework of the European research projects tempQsim (EVK1-CT2002-00112), MIRAGE (ENV-2007-1), LIFE + TRivers (LIFE13 ENV/ES/000341) and the IRBAS project (www.irbas.fr). IRBAS was supported by the Centre for Synthesis and Analysis of Biodiversity (CESAB) and part of this work was based upon work from COST Action CA15113 (SMIRES, Science and Management of Intermittent Rivers and Ephemeral Streams, www.smires.eu), supported by COST (European Cooperation in Science and Technology). The Italian contribution was supported by the INHABIT project (LIFE08 ENV/IT/00413), granted by the European Union under the LIFE + Environment Policy and Governance 2008 program. M.M. Sánchez-Montoya was supported by a Marie-Curie postdoctoral fellowship (CLITEMP Project 330466; FP7-people-2012-IEF). Nuria Bonada would like to thank Núria Cid for her valuable comments on water management in Spain. The authors would like to thank Brian Zimmerman for improving the use of English in the manuscript.

\section{References}

Acuña, V., Datry, T., Marshall, J., Barceló, D., Dahm, C.N., Ginebreda, A., McGregor, G., Sabater, S., Tockner, K., Palmer, M.A., 2014. Why should we care about temporary waterways? Science 343, 1080-1081.
Acuña, V., Giorgi, A., Muñoz, I., Uehlinger, U., Sabater, S., 2004. Flow extremes and benthic organic matter shape the metabolism of a headwater Mediterranean stream. Freshw. Biol. 49, 960-971.

Acuña, V., Muñoz, I., Giorgi, A., Omella, M., Sabater, F., Sabater, S., 2005. Drought and postdrought recovery cycles in an intermittent Mediterranean stream: structural and functional aspects. J. North Am. Benthol. Soc. 24, 919-933.

Afonso, J., 2007. Water scarcity and droughts: main issues at European level and the Portuguese experience. Water Scarcity and Drought - A Priority of the Portuguese Presidency. Ministério do Ambiente, do Ordenamento do Território e do Desenvolvimento Regional (127 pp).

Alba-Tercedor, J., Jáimez-Cuéllar, P., Álvarez, M., Avilés, J., Bonada, N., Casas, J., Mellado, A Ortega, M., Pardo, I., Prat, N., Rieradevall, M., Robles, S., Sáinz-Cantero, C.E., SánchezOrtega, A., Suárez, M.A., Toro, M., Vidal-Abarca, M.R., Vivas, S., Zamora-Muñoz, C., 2002. Caracterización del estado ecológico de ríos mediterráneos ibéricos mediante el índice IBMWP (antes BMWP'). Limnetica 21, 175-185.

Amalfitano, S., Fazi, S., Zoppini, A., Barra Caracciolo, A., Grenni, P., Puddu, A., 2008. Responses of benthic bacteria to experimental drying in sediments from Mediterranean temporary rivers. Microb. Ecol. 55, 270-279.

Antonellini, M., Mollema, P., Giambastiani, B., Banzola, E., Bishop, K., Caruso, L., Minchio, A., Pellegrini, L., Sabia, M., Ulazzi, E., Gabbianelli, G., 2008. Salt water intrusion in the coastal aquifer of the southern Po-plain. Hydrogeol. J. Italy.

Aparicio, E., Vargas, M.J., Olmo, J.M., de Sostoa, A., 2000. Decline of native freshwater fishes in a Mediterranean watershed on the Iberian peninsula: a quantitative assessment. Environ. Biol. Fish 59, 11-19.

Arce, M., Sánchez-Montoya, M.M., Gómez, R., 2015. Nitrogen processing following experimental sediment rewetting in isolated pools in an agricultural stream of a semiarid region. Ecol. Eng. 77, 233-241.

Arce, M., Sánchez-Montoya, M.M., Vidal-Abarca, M.R., Suárez, M.L., Gómez, R., 2014. Implications of flow intermittency on sediment nitrogenavailability and processing rates in a Mediterranean headwaterstream. Aquat. Sci. 76, 173-186.

Argyroudi, A., Chatzinikolaou, Y., Poirazidis, K., Lazaridou, M., 2009. Do intermittent and ephemeral Mediterranean rivers belong to the same river type? Aquat. Ecol. 43, 465-476.

Arscott, D.B., Larned, S., Scarsbrook, M.R., Lambert, P., 2010. Aquatic invertebrate community structure along an intermittence gradient: Selwyn River, New Zealand. J. N. Am. Benthol. Soc. 29, 530-545.

Arthington, A.H., Bernardo, J.M., Ilhèu, M., 2014. Temporary rivers: linking ecohydrology, ecological quality and reconciliation ecology. River Res. Appl. 30, 1209-1215.

Barthès, A., Leflaive, J., Coulon, S., Peres, F., Rols, J.L., Ten-Hage, L., 2014. Impact of Drought on Diatom Communities and the Consequences for the Use of Diatom Index Values in the River Maureillas (Pyrénées-Orientales, France). River Res. Appl. n/a.

Belmar, O., Velasco, J., Gutiérrez-Cánovas, C., Mellado-Díaz, A., Millán, A., Wood, P.J., 2012 The influence of natural flow regimes on macroinvertebrate assemblages in a semiarid Mediterranean basin. Ecohydrology 6, 363-379.

Belmar, O., Velasco, J., Martinez-Capel, F., 2011. Hydrological classification of natural flow regimes to support environmental flow assessments in intensively regulated Mediterranean rivers, Segura River basin (Spain). Environ. Manag. 47, 992-1004.

Benejam, L., Angermeier, P.L., Munne, A., Garcia-Berthou, E., 2010. Assessing effects of water abstraction on fish assemblages in Mediterranean streams. Freshw. Biol. 55 628-642.

Benítez, C., Schmidt, G., 2012. Analysis of the implementation of Environmental Flows in the wider context of the river basin management plans (Report drafted in the framework of the Comparative Study of Pressures and Measures in the Major River Basin Management Plans. Task 3d: Water Abstraction and Water Use).

Benstead, J.P., Leigh, D.S., 2012. An expanded role of river networks. Nat. Geosci. 5, 678-679.

Bernal, S., von Schiller, D., Sabater, F., Martı, E., 2013. Hydrological extremes modulate nutrient dynamics in Mediterranean climate streams across different spatial scales. Hydrobiologia 719, 31-42.

Blake, W.H., Theocharopoulos, S.P., Skoulikidis, N., Clark, P., Tountas, P., Hartley, R., Amaxidis, Y., 2010. Wildfire impacts on hillslope sediment and phosphorus yields. J. Soils Sediments 10, 671-682.

Blondel, J.J., Aronson, J., Bodiou, J.Y., Boeuf, G., 2010. The Mediterranean Region: Biological Diversity in Space and Time. Oxford University Press.

Bobori, D.C., Economidis, P.S., 2006. Freshwater fishes of Greece: their biodiversity, fisheries and habitats. J. Aquat. Ecosyst. Health 9, 407-418.

Bonada, N., Resh, V.H., 2013. Mediterranean-climate streams and rivers: geographically separated but ecological comparable freshwater systems. Hydrobiologia 719, 1-29.

Bonada, N., Dolédec, S., Statzner, B., 2007a. Taxonomic and biological trait differences of stream macroinvertebrate communities between mediterranean and temperate regions: implications for future climatic scenarios. Glob. Chang. Biol. 13, 1658-1671.

Bonada, N., Rieradevall, M., Dallas, H., Davis, J., Day, J., Figueroa, R., Resh, V.H., Prat, N., 2008. Multi-scale assessment of macroinvertebrate richness and composition in Mediterranean-climate rivers. Freshw. Biol. 53, 772-788.

Bonada, N., Rieradevall, M., Prat, N., 2007b. Macroinvertebrate community structure and biological traits related to flow permanence in a Mediterranean river network. Hydrobiologia 589, 91-106.

Bradford, R.B., 2000. Drought events in Europe. In: Vogt, J.V., Somma, F. (Eds.), Drought and Drought Mitigation in Europe. Kluwer Academic Publishers, Dordrecht, Netherlands, p. 319.

Bruno, D., Belmar, O., Sánchez-Fernández, D., Velasco, J., 2014. Environmental determinants of woody and herbaceous riparian vegetation patterns in a semi-arid Mediterranean basin. Hydrobiologia 30, 45-57.

Bruno, D., Gutiérrez-Cánovas, C., Sánchez-Fernández, D., Velasco, J., Nilsson, C., 2016. Impacts of environmental filters on functional redundancy in riparian vegetation. J. Appl. Ecol. n/a. 
Buendia, C., Batalla, R.J., Sabater, S., Palau, A., Marce, R., 2015. Runoff trends driven by climate and afforestation in a Pyrenean basin. Land Degrad. Develop. n/a.

Buffagni, A., Erba, S., 2014. Linee guida per la valutazione della componente macrobentonica fluviale ai sensi del DM 260/2010. ISPRA, Manuali e Linee Guida $107 / 2014$, p. 83 (in Italian).

Buffagni, A., Munafò, M., Tornatore, F., Bonamini, I., Didomenicantonio, A., Mancini, L. Martinelli, A., Scanu, G., Sollazzo, C., 2006a. Elementi di base per la definizione di una tipologia per i fiumi italiani in applicazione della Direttiva 2000/60/EC. IRSACNR Notiziario dei Metodi Analitici, Dicembre 2006. 1, pp. 2-19 (ISSN 1974-8345) (in Italian),

Buffagni, A., Erba, S., Cazzola, M., Murray-Bligh, J., Soszka, H., Genoni, P., 2006b. The STAR common metrics approach to the WFD intercalibration process: full application for small, lowland rivers in three European countries. In: Furse, M., Hering, D., Brabec, K., Buffagni, A., Sandin, L., Verdonschot, P.M. (Eds.), The Ecological Status of European Rivers: Evaluation and Intercalibration of Assessment Methods. Developments in Hydrobiology. Springer, Netherlands, pp. 379-399.

Buffagni, A., Armanini, D.G., Erba, S., 2009. Does the lentic-lotic character of rivers affect invertebrate metrics used in the assessment of ecological quality? J. Limnol. 68, 95-109.

Buffagni, A., Erba, S., Armanini, D.G., 2010. The lentic-lotic character of Mediterranean rivers and its importance to aquatic invertebrate communities. Aquat. Sci. 72, 45-60.

Buffagni, A., Tenchini, R., Cazzola, M., Erba, S., Balestrini, R., Belfiore, C., Pagnotta, R., 2016. Detecting the impact of bank and channel modification on invertebrate communities in Mediterranean temporary streams (Sardinia, SW Italy). Sci. Total Environ. 565, $1138-1150$.

Bunn, S.E., Arthington, A.H., 2002. Basic principles and ecological consequences of altered flow regimes for aquatic biodiversity. Environ. Manag. 30, 492-507.

Bussettini, M., Percopo, C., Lastoria, B., Mariani, S., 2015. A method for characterizing the stream flow regime in Europe. Engineering Geology for Society and Territory. 3, pp. 323-326.

Cañedo-Argüelles, M., Bundschuh, M., Gutiérrez-Cánovas, C., Kefford, B.J., Prat, N., Trobajo R., Schäfer, R.B., 2014. Effects of repeated salt pulses on ecosystem structure and functions in a stream mesocosm. Sci. Total Environ. 476, 634-642.

Cañedo-Argüelles, M., Hawkins, C.P., Kefford, B.J., Schäfer, R.B., Dyack, B.J., Brucet, S. Buchwalter, D., Dunlop, J., Frör, O., Lazorchak, J., Coring, E., Fernandez, H.R. Goodfellow, W., González Achem, A.L., Hatfield-Dodds, S., Karimov, B.K., Mensah, P., Olson, J.R., Piscart, C., Prat, N., Ponsá, S., Schulz, C.-J., Timpano, A.J., 2016. Saving freshwater from salts. Science 351, 914-916.

Cañedo-Argüelles, M., Kefford, B.J., Piscart, C., Prat, N., Schäfer, R.B., Schulz, C.J., 2012. Salinisation of rivers: an urgent ecological issue. Environ. Pollut. 173, 157-167.

Casas-Ruiz, J.P., Tittel, J., von Schiller, D., Catalán, N., Gómez-Gener, L., Obrador, B., Zwirnmann, E., Sabater, S., Marcé, R., 2016. Drought-induced discontinuities in the source and biodegradation of dissolved organic matter in a Mediterranean river. Biogeochemistry $127,125-139$.

Cemagref, 1982. Etude des méthodes biologiques d'appréciation quantitavive de la qualité des eaux. Rapport QE Lyon Bassin Rhône-Méditerranée-Corse.

Chadzichristidi, K., Beltsios, S., Papakonstantinou, A., 1991. Pinios River water quality measurements. 2nd Conference on Environmental Science and Technology, Lesvos, pp. 630-639 (in Greek with English abstract).

Cid, N., Verkaik, I., García-Roger, E.M., Rieradevall, M., Bonada, N., Sánchez-Montoya M.M., Gómez, R., Suárez, M.L., Vidal-Abarca, M.R., Demartini, D., Buffagni, A., Erba, S., Karaouzas, I., Skoulikidis, N., Prat, N., 2016. A biological tool to assess flow connectivity in reference temporary streams from the Mediterranean Basin. Sci. Total Environ. 540, 178-190.

Clavero, M., Hermoso, V., Levin, N., Kark, S., 2010. Geographical linkages between threats and imperilment in freshwater fish in the Mediterranean basin. Divers. Distrib. 16, 744-754.

Clavero, M., Prenda, J., Delibes, M., 2003. Trophic diversity of the otter (Lutra lutra L.) in temperate and Mediterranean freshwater habitats. J. Biogeogr. 30, 761-769.

Coimbra, C.N., Graça, M.A.S., Cortes, R.M., 1996. The effects of a basic effluent on macroinvertebrate community structure in a temporary Mediterranean river. Environ. Pollut. 94, 301-307.

Conacher, A.J., Sala, M., 1998. Land Degradation in Mediterranean Environments of the World: Nature and Extent, Causes and Solutions. Wiley, Chichester/New York.

Cooper, S.D., Lake, P.S., Sabater, S., Melack, J.M., Sabo, J.L., 2013. The effects of land use changes on streams and rivers in Mediterranean climates. Hydrobiologia 719, 383-425.

Corti, R., Datry, T., 2012. Invertebrates and sestonic matter in an advancing wetted front travelling down a dry river bed (Albarine, France). Freshw. Sci. 31, $1187-1201$

Corti, R., Datry, T., 2014. Drying of a temperate, intermittent river has little effect on adjacent riparian arthropod communities. Freshw. Biol. 59, 666-678.

Corti, R., Datry, T., 2015. Terrestrial and aquatic invertebrates in the riverbed of an intermittent river: parallels and contrasts in community organisation. Freshw. Biol. (in press).

Corti, R., Datry, T., Drummond, L., Larned, S.T., 2011. Natural variation in immersion and emersion affects breakdown and invertebrate colonization of leaf litter in a temporary river. Aquat. Sci. 73, 537-550.

Corti, R., Larned, S., Datry, T., 2013. Pitfall traps and quadrat searches for sampling grounddwelling invertebrates in dry riverbeds. Hydrobiologia 717, 13-26.

Costa, A.C., Soares, A., 2009. Trends in extreme precipitation indices derived from a daily rainfall database for the South of Portugal. Int. J. Climatol. 29, 1956-1975.

Cowling, R.M., Rundel, P.W., Lamont, B.B., Arroyo, M.K., Arianoutsou, M., 1996. Plant diversity in Mediterranean climate regions. Tree 11, 362-366.

Cuttelod, A., García, N., Abdul Malak, D., Temple, H., Katariya, V., 2008. The Mediterranean: a biodiversity hotspot under threat. In: Vié, J.C., Hilton-Taylor, C., Stuart, S.N. (Eds.),
The 2008 Review of The IUCN Red List of Threatened Species IUCN Gland, Switzerland (13 pp).

Dahm, C.D., Boulton, A.J., Bonada, N., Fritz, K., Leigh, C., Sauquet, E., Hugueny, B., Tockner, K., 2016. Significance of first pulses of flow on river biogeochemistry. Biogeochemistry (in review)

Dalezios, N.R., Loukas, A., Bampzelis, D., 2002. Spatial variability of reference evapotranspiration in Greece. Phys. Chem. Earth 27, 1031-1038.

Darwall, W., Carrizo, S., Numa, C., Barrios, V., Freyhof, J., Smith, K., 2014. Freshwater Key Biodiversity Areas in the Mediterranean Basin Hotspot: Informing Species Conservation and Development Planning in Freshwater Ecosystems. International Union for Conservation of Nature, Cambridge.

Datry, T., 2012. Benthic and hyporheic invertebrate assemblages along a flow intermittence gradient: effects of duration of dry events. Freshw. Biol. 57, 563-574.

Datry, T., Bonada, N., Heino, J., 2016a. Towards understanding the organisation of metacommunities in highly dynamic ecological systems. Oikos 125, 149-159.

Datry, T., Corti, R., Foulquier, A., von Schiller, D., Tockner, K., 2016c. One for all, all for one: a global research network to expand river geoscience. Eos 97

Datry, T., Larned, S.T., Tockner, K., 2014a. Intermittent rivers: a challenge for freshwater ecology. Bioscience 64, 229-235.

Datry, T., Larned, S.T., Fritz, K.M., Bogan, M.T., Wood, P.J., Meyer, E.I., Santos, A.N., 2014b. Broad scale patterns of invertebrate richness and community composition in temporary rivers: effects of flow intermittence. Ecography 37, 94-104.

Datry, T., Arscott, D.B., Sabater, S., 2011. Recent perspectives on temporary river ecology. Aquat. Sci. 73, 453-457.

Datry, T., Pella, H., Leigh, C., Bonada, N., Hugueny, B., 2016b. A landscape approach to advance intermittent river ecology. Freshw. Biol. 1-14.

De Castro, M., Martin-Vide, J., Alonso, S., 2005. The climate of Spain: past, present and scenarios for the 21st century. In: Moreno, J.M. (Ed.), A Preliminary General Assessment of the Impacts in Spain Due to the Effects of Climate Change. Spanish Ministry of Environment, Madrid, pp. 1-62.

De Girolamo, A.M., Gallart, F., Pappagallo, G., Santese, G., Lo Porto, A., 2015a. An eco-hydrological assessment method for temporary rivers. The Celone and Salsola rivers case study (SE, Italy). Ann. Limnol. Int. J. Lim. 51, 1-10.

De Girolamo, A.M., Lo Porto, A., Pappagallo, G., Tzoraki, O., Gallart, F., 2015b. The hydrological status concept. Application at a temporary river (Candelaro, Italy). River Res. Applic. 31, 892-903.

De Girolamo, A.M., Calabrese, A., Pappagallo, G., Santese, G., Lo Porto, A., 2012. Impact of anthropogenic activities on a temporary river. Fresenius Environ. Bull. 21, $3278-3286$.

Decret, 2007. Décret n 2007-1760 du 14 décembre 2007 portant dispositions relatives aux régimes d'autorisation et de déclaration au titre de la gestion et de la protection de l'eau et des milieux aquatiques, aux obligations imposées à certains ouvrages situés sur les cours d'eau, à l'entretien et à la restauration des milieux aquatiques et modifiant le code de l'environnement.

Demetropoulou, L., Nikolaidis, N., Papadoulakis, V., Tsakiris, K., Koussouris, T., Kalogerakis, N., Koukaras, K., Chatzinikolaou, A., Theodoropoulos, K., 2010. Water framework directive implementation in Greece: introducing participation in water governance the case of the Evrotas River basin management plan. Env. Pol. Gov. 20, 336-349.

Department of Meteorology of Cyprus, 2014. The Climate of Cyprus. Website of the Department of Meteorology. Republic of Cyprus, Ministry of Agriculture Available from:. http://www.moa.gov.cy/moa/ms/ms.nsf/DMLcyclimate_en/DMLcyclimate_ en?OpenDocument (Accessed October 24, 2014).

Dieter, D., von Schiller, D., Garcla-Roger, E.M., Sanchez-Montoya, M.M., Gomez, R., MoraGomez, J., Sangiorgio, F., Gelbrecht, J., Tockner, K., 2011. Preconditioning effects of intermittent stream flow on leaf litter decomposition. Aquat. Sci. 73, 599-609.

EC, 2015. Report on the implementation of the Water Framework Directive River Basin Management Plans Member State: Greece. Communication from the European Commission to the European Parliament and the Council. The Water Framework Directive and the Floods Directive: Actions Towards the 'Good Status' of EU Water and to Reduce Flood Risks. EC, SWD, 54 final.

EC-JRC, 2005. Climate change and the European water dimension. A Report to the European Water Directors, EU Report No. 21553.

Economou, A., Barbieri, R., Daoulas, C., Psarras, T., Stoumboudi, M., Bertahas, H., Giakoumi, S., Patsias, A., 1999. Endangered freshwater fish of western Greece and the Peloponnese: Distribution, abundance, threats and measures for protection. Final Technical Report. National Centre for Marine Research, p. 341.

EEA, 2008. Impacts of Europe's Changing Climate - 2008 Indicator-based Assessment. EEA-JRC-WHO Report. EEA, Copenhagen.

EEA, 2009. Water Scarcity and Drought: towards a European Water Scarcity and Drought Network (WSDN) prepared by Kossida, M., Koutiva, I., Makropoulos, C., Monokrousou, K., Mimikou, M., Fons-Esteve, Iglesias, A. (107 p).

EEA, 2012. Climate change, impacts and vulnerability in Europe 2012. An indicator-based report. EEA Report No 12/2012.

Emilia-Romagna, A.R.P.A., 2015. In: Ferri, D., Franceschini, S. (Eds.), Valutazione dello stato delle acque superficiali fluviali 2010-2013, p. 105 (in Italian)

ENVECO S.A. and I.A.CO Ltd., 2013. Review and update of article 5 of Directive 2000/60/EC (water reservoirs) and classification of water status (rivers, natural lakes and water reservoirs), that will establish baseline information and data for the 2nd Cyprus River Basin Management Plan. Report on the classification of water status (rivers, natural lakes, water reservoirs). Contract No.: YY 02/2013. Final Report. Water Development Department, Ministry of Agriculture, Natural Resources and Environment, Nicosia-Cyprus [online]. Available from: http://www.moa.gov.cy/moa/wdd/wdd. nsf/all/AAA019E372936A76C2257E6500271FB4/\$file/Ekthesi_art5_Tax_river_dams. pdf [Accessed September 27, 2015]

Erba, S., Furse, M.T., Balestrini, R., Christodoulides, A., Ofenböck, T., van de Bund, W., Wasson, J.G., Buffagni, A., 2009. The validation of common European class boundaries 
for river benthic macroinvertebrates to facilitate the intercalibration process of the Water Framework Directive. Hydrobiologia 633 (2009), 17-31.

Esteban-Parra, M.J., Rodrigo, F.S., Castro-Díez, Y., 1998. Spatial and temporal patterns of precipitation in Spain for the period 1880-1992. Int. J. Climat. 18, 1557-1574.

Estrela, T., Vargas, E., 2012. Drought management plans in the European Union. The case of Spain. Water Resour. Manag. 26, 1537-1153.

European Commission, 2013. COMMISSION DECISION of 20 September 2013 Establishing, Pursuant to Directive 2000/60/EC of the European Parliament and of the Council, the Values of the Member State Monitoring System Classifications as a Result of the Intercalibration Exercise and Repealing Decision 2008/915/EC. (2013/480/EU).

European Commission, 2015. Ecological flows in the implementation of the Water Framework Directive. WFD CIS Guidance Document No. 31 (106 pp).

Feio, M.J., Aguiar, F.C., Almeida, S.F.P., Ferreira, J., Ferreira, M.T., Elias, C., Serra, S.R.S., Buffagni, A., Cambra, J., Chauvin, C., Delmas, F., Dörflinger, G., Erba, S., Flor, N., Ferréol, M., Germ, M., Mancini, L., Manolaki, P., Marcheggiani, S., Minciardi, M.R., Munné, A., Papastergiadou, E., Prat, N., Puccinelli, C., Rosebery, J., Sabater, S., Ciadamidaro, S., Tornés, E., Tziortzis, I., Urbanic, G., Vieira, C., 2014b. Least disturbed conditions for European Mediterranean rivers. Sci. Total Environ. 476-477, 745-756.

Feio, M.J., Ferreira, J., Buffagni, A., Erba, S., Dörflinger, G., Ferréol, M., Munné, A., Prat, N., Tziortzis, I., Urbanič, G., 2014a. Comparability of ecological quality boundaries in the Mediterranean basin using freshwater benthic invertebrates. Statistical options and implications. Sci. Total Environ. 476, 777-784.

Foulquier, A., Pesce, S., Artigas, J., Datry, T., 2015. Drying responses of microbial litter decomposition and associated fungal and bacterial communities are not affected by emersion frequency. Freshw. Sci. 34, 000.

Gallart, F., Llorens, P., 2004. Observations on land cover changes and the headwaters of the Ebro catchment, water resources in Iberian Peninsula. Phys. Chem. Earth 29, 769-773.

Gallart, F., Amaxidis, Y., Botti, P., Cane, B., Castillo, V., Chapman, P., Froebrich, J., Garcia, J. Latron, J., Llorens, P., Lo Porto, A., Morais, M., Neves, N., Ninov, P., Perrin, J.L., Ribarova, I., Skoulikidis, N., Tournoud, M.G., 2008. Investigating hydrological regimes and processes in a set of catchments with temporary waters. Hydrolog. Sci. J. 53, 618-628.

Gallart, F., Llorens, P., Latron, J., Cid, N., Rieradevall, M., Prat, N., 2016. Validating alternative methodologies to estimate the regime of temporary rivers when flow data are unavailable. Sci. Total Environ. 565, 1001-1010.

Gallart, F., Prat, N., García-Roger, E.M., Latron, J., Rieradevall, M., Llorens, P., Barberá, G.G., Brito, D., De Girolamo, A.M., Lo Porto, A., Buffagni, A., Erba, S., Neves, R., Nikolaidis, N.P., Perrin, J.L., Querner, E.P., Quiñonero, J.M., Tournoud, M.G., Tzoraki, O., Skoulikidis, N., Gómez, R., Sánchez-Montoya, M.M., Froebrich, J., 2012. A novel approach to analysing the regimes of temporary streams in relation to their controls on the composition and structure of aquatic biota. Hydrol. Earth Syst. Sci. 16, 3165-3182.

García-Roger, E.M., Sánchez-Montoya, M.M., Cid, N., Erba, S., Karaouzas, I., Verkaik, I., Rieradevall, M., Gómez, R., Suárez, M.L., Vidal-Abarca, M.R., Demartini, D., Buffagni, A., Skoulikidis, N., Bonada, N., Prat, N., 2013. Spatial scale effects on taxonomic and biological trait diversity of aquatic macroinvertebrates in Mediterranean streams. Fundam. Appl. Limnol. 183/2, 89-105.

García-Roger, E.M., Sánchez-Montoya, M.M., Gómez, R., Suárez, M.L., Vidal-Abarca, M.R., Latron, J., Rieradevall, M., Prat, N., 2011. Do seasonal changes in habitat features influence aquatic macroinvertebrate assemblages in permanent vs temporary Mediterranean streams? Aquat. Sci. 73, 567-579.

García-Ruiz, J.M., López-Moreno, J.I., Vicente-Serrano, S.M., Lasanta-Martínez, T., Beguería, S., 2011. Mediterranean water resources in a global change scenario. Earth-Sci. Rev. $105,121-139$.

Gasith, A., Resh, V.H., 1999. Streams in Mediterranean climate region: abiotic influences and biotic responses to predictable seasonal events. Annu. Rev. Ecol. Syst. 30, 51-81.

Georgiou, A., 2002. Assessment of Groundwater Resources WDD/FAO.

Giordano, R., Romano, Preziosi E., 2013. Integration of local and scientific knowledge to support drought impact monitoring: some hints from an Italian case study. Nat. Hazards 69:523-544. http://dx.doi.org/10.1007/s11069-013-0724-9.

Gómez, R., Arce, M.I., Sánchez, J.J., Sánchez-Montoya, M.M., 2012. The effects of drying on sediment nitrogen content in a Mediterranean intermittent stream: a microcosms study. Hydrobiologia 679, 43-59.

Gómez, R., Hurtado, I., Suárez, M.L., Vidal-Abarca, M.R., 2005. Ramblas in south-east Spain: threatened and valuable ecosystems. Aquat. Conserv. 15, 387-402.

Gómez-Gener, L., Obrador, B., Marcé, R., Acuña, V., Catalán, N., Casas-Ruiz, J.P., Sabater, S., Muñoz, I., von Schiller, D., 2016. When water vanishes: magnitude and regulation of carbon dioxide emissions from dry temporary streams. Ecosystems (in press).

Graça, M.A.S., Pinto, P., Cortes, R., Coimbra, N., Oliveira, S., Morais, M., Carvalho, M.J., Malo, J., 2004. Factors affecting macroinvertebrate richness and diversity in Portuguese streams: a two-scale analysis. Int. Rev. Hydrobiol. 89, 151-164.

Grantham, T.E., Figueroa, R., Prat, N., 2013. Water management in mediterranean river basins: a comparison of management frameworks, physical impacts, and ecological responses. Hydrobiologia 719, 451-482.

Gumiero, B., Maiolini, B., Surian, N., Rinaldi, M., Boz, B., Moroni, F., 2009. The Italian rivers. In: Tockner, K., Uehlinger, U., Robinson, C.T. (Eds.), Rivers of Europe. Academic Press, London, UK.

Hall, R.K., Husby, P., Wolinsky, G., Hansen, O., Mares, M., 1998. Site access and sample frame issues for R-EMAP Central Valley, California, stream assessment. Environ. Monit. Assess. 51, 357-367.

Hassan, M.A., Egozi, R., 2001. Impact of wastewater discharge on the channel morphology of ephemeral streams. Earth Surf. Process. Landf. 26, 1285-1302.

Hershkovitz, Y., Gasith, A., 2013. Resistance, resilience, and community dynamics in mediterranean-climate streams. Hydrobiologia 719, 59-75.

Ibáñez, C., Carola, N., 2010. Impacts of Water Scarcity and Drought on Iberian Aquatic Ecosystems. Policy Note 04-0910. Water Science and Policy Center.
ICOLD, 2015. Number of Dams by Country Members. International Commission on Large Dams [online]. Available from:. http://www.icold-cigb.org/GB/World_register/ general_synthesis.asp?IDA=206 (Accessed September 28, 2015).

INAG, 2001. Plano nacional da água - introdução, caracterização e diagnóstico da situação actual dos recursos hídricos. Vol.1. Instituto da Água, p. E2.

Isendahl, N., Schmidt, G., 2006. Drought in the Mediterranean: WWF Policy Proposals, WWF/Adena, WWF Mediterranean Programme, WWF Germany. July 2006 (45 p).

Izagirre, O., Agirre, U., Bermejo, M., Pozo, J., Elosegi, A., 2008. Environmental controls of whole-stream metabolism as depicted from continuous monitoring of Basque streams. J. N. Am. Benthol. Soc. 27, 252-268.

Jacobson, P.J., Jacobson, K.M., Angermeier, P.L., Cherry, D.S., 2004. Variation in material transport and water chemistry along a large ephemeral river in the Namid Desert. Freshw. Biol. 44, 481-491.

Karaouzas, I., Skoulikidis, N., 2011. Influence of hydrologic variation to the ecological status of Mediterranean streams receiving organic wastewaters. 7th Symposium for European Freshwater Sciences. Girona, Spain, 27 June-1 July. Book of abstracts, p. 108

Karaouzas, I., Skoulikidis, N., Giannakou, U., Albanis, T.A., 2011. Spatial and temporal effects of olive mill wastewaters to stream macroinvertebrates and aquatic ecosystems status. Water Res. 45, 6334-6346.

Karavokyris, G., Partners Consulting Engineers SA, Kaimaki, S.P., 2011. Implementation of Articles 11, 13 and 15 of the Water Framework Directive (2000/60/EC) in Cyprus. Annex I. Detailed River Basin Management Plan. (Contract 97/2007). Ministry of Agriculture and Natural Resources. - Annex VII. Final Water Policy Report. (Contract 97/ 2007). Ministry of Agriculture and Natural Resources. Department of Water Development.

Kirkby, M.J., Gallart, F., Kjeldsen, T.R., Irvine, B.J., Froebrich, J., Lo Porto, A., De Girolamo, A. 2011. Classifying low flow hydrological regimes at a regional scale. Hydrol. Earth Sys. Sci. $15,3741-3750$.

Köppen, W., 1936. Das geographishe System der Klimate. Koppen and Geiger Eds Handbuch der Klimatologie 3. Gebrueder Borntraeger, Berlin, p. 46.

Lambrakis, N., Marinos, P., 2005. The salinisation of coastal aquifers in Greece; A general review. COST 621 (Groundwater Management of Coastal Karstic Aquifers) Edited by Luigi Tulipano.

Larned, S.T., Datry, T., Arscott, D.B., Tockner, K., 2010. Emerging concepts in temporaryriver ecology. Freshw. Biol. 55, 717-738.

Larned, S., Datry, T., Robinson, C.T., 2007. Invertebrate and microbial responses to inundation in an ephemeral river reach in New Zealand: effects of preceding dry periods. Aquat. Sci. 69, 554-567.

LDK Consultants SA, Ecos Consulting SA, 2015. Draft Programme of Measures of the River Basin Management Plan of Cyprus (Period 2016-2021). Water Development Department [online]. Available:. http://www.moa.gov.cy/moa/wdd/wdd.nsf/all/ 7D60FEB84FCA5DF1C2257F01003626A7/\$file/Programa_Metron.pdf?openelement (Accessed October 11, 2016).

Leigh, C., Bonada, N., Boulton, A.J., Hugueny, B., Larned, S., Vander Vorste, R., Datry, T., 2015b. Invertebrate community responses and the dual roles of resistance and resilience to drying in intermittent rivers. Aquat. Sci. (in press).

Leigh, C., Boulton, A.J., Courtwright, J.L., Fritz, K., May, C.L., Walker, R.H., Datry, T., 2015a Ecological research and management of intermittent rivers: an historical review and future directions. Freshw. Biol. (in press).

Livada, I., Asimakopoulos, D.N., 2005. Individual seasonality index of rainfall regimes in Greece. Clim. Res. 28, 155-161.

Lopez-Doval, J.C., Ginebreda, A., Caquet, T., Dahm, C.N., Petrovic, M., Barcelo, D., Munoz, I., 2013. Pollution in mediterranean-climate rivers. Hydrobiologia 719, 427-450.

Loukas, A., Mylopoulos, N., Vasiliades, L., 2007. A modelling system for the evaluation of water resources management strategies in Thessaly, Greece. Water Resour Manag. $21,1673-1702$.

Ludwig. W.., Dumont, E, Meybeck, M. Heussner, S, 2009. River discharges of water and nutrients to the Mediterranean and Black Sea: major drivers for ecosystem changes during past and future decades? Prog. Oceanogr. 80, 199-217.

Magalhães, M.F., Batalha, D.C., Collares-Pereira, M.J., 2002. Gradients in stream fish assemblages across a Mediterranean landscape: contributions of environmental factors and spatial structure. Freshw. Biol. 47, 1015-1031.

Magalhães, M.F., Beja, P., Schlosser, I.J., Collares-Pereira, M.J., 2007. Effects of multi-year droughts on fish assemblages of seasonally drying Mediterranean streams. Freshw. Biol. 52, 1494-1510.

Magoulick, D.D., Kobza, R.M., 2003. The role of refugia for fishes during drought: a review and synthesis. Freshw. Biol. 48, 1186-1198.

Mas-Martí, E., García-Berthou, E., Sabater, S., Tomanova, S., Muñoz, I., 2010. Comparing fish assemblages and trophic ecology of permanent and intermittent reaches in a Mediterranean stream. Hydrobiologia 657, 167-180.

Matthews, W.J., Matthews, E.M., 2003. Effects of drought on fish across axes of space, time and ecological complexity. Freshw. Biol. 48, 1232-1253.

MATTM, 2008. Italian Ministry of Environment and Land and Sea Protection. Decreto 16 giugno 2008, n. 131. Regolamento recante i criteri tecnici per la caratterizzazione dei corpi idrici (tipizzazione, individuazione dei corpi idrici, analisi delle pressioni) per la modifica delle norme tecniche del decreto legislativo 3 aprile 2006, n. 152, recante: "Norme in materia ambientale", predisposto ai sensi dell'articolo 75 , comma 4, dello stesso decreto. Gazzetta Ufficiale n.187 del 11-8-2008 - Suppl. Ordinario n. 189 (in Italian).

Mazor, R.D., Stein, E.D., Ode, P.R., Schiff, K., 2014. Integrating intermittent streams into watershed assessments: applicability of an index of biotic integrity. Freshw. Sci. 33, 459-474.

McClain, M.E., Boyer, E.W., Dent, C.L., Gergel, S.E., Grimm, N.B., Groffman, P.M., Hart, S.C., Harvey, J.W., Johnston, C.A., Mayorga, E., McDowell, W.H., Pinay, G., 2003. Biogeochemical hot spots and hot moments at the interface of terrestrial and aquatic ecosystems. Ecosystems 6, 301-312. 
McDonough, O.T., Hosen, J.D., Palmer, M.A., 2011. Temporary streams: the hydrology, geography and ecology of non-perennially flowing waters. In: Elliot, H.S., Martin, L.E. (Eds.), River Ecosystems: Dynamics. Nova Science Publ. Inc., Management and Conservation, pp. 259-289.

Meyer, J.L., Wallace, J.B., 2001. Lost linkages and lotic ecology: rediscovering small streams. In: Press, M.C., Huntly, N.J., Levin, S. (Eds.), Ecology: Achievement and Challenge. Blackwell Science Ltd., London.

Meyer, J.L., Strayer, D.L., Wallace, J.B., Eggert, S.L., Helfman, G.S., Leonard, N.E., 2007. The contribution of headwater streams to biodiversity in river networks. J. Am. Water Resour. Assoc. 43, 86-103.

Milnes, E., 2011. Process-based groundwater salinisation risk assessment methodology: application to the Akrotiri aquifer (southern Cyprus). J. Hydrol. 399 (1-2), 29-47.

Milnes, E., Renard, P., 2004. The problem of salt recycling and seawater intrusion in coastal irrigated plains: an example from the Kiti aquifer (Southern Cyprus). J. Hydrol. 288 (3-4), 327-343.

Ministry for Agriculture, Natural Resources and Environment, 2011. Implementation of the Articles 11,13 and 15 of the WFD in Cyprus. Annex 1: Analytical River Basin Management Plan (273 pp). (in Greek).

Ministry for Development, 2003. Master Plan for the Management of Greek Water Resources. Directorate of Aquatic and Natural Resources, Athens (519 pp. (in Greek)).

Morais, M.M., Pedro, A., Rosado, J., Pinto, P., 2009. Temporary rivers: from excess to scarcity. In: Duarte, L.M.G., Pinto, P. (Eds.), Sustainable Development: Energy, Environment and Natural Disasters. Fundação Luis de Molina, Universidade de Évora, pp. 37-49.

Morais, M., Pinto, P., Guilherme, P., Rosado, J., Antunes, I., 2004. Assessment of temporary streams: the robustness of metric and multimetric indices under different hydrological conditions. Hydrobiologia 516, 229-249.

Mulas, G., Erbì, G., Pintus, M.T., Staffa, F., Puddu, D., 2009. Caratterizzazione dei corpi idrici della sardegna "relazione generale" decreto del ministero dell'ambiente e della tutela del territorio e del mare n. 131 del 16 giugno 2008. Regione Autonoma della Sardegna. Delibera del Comitato Istituzionale dell'Autorità di Bacino della Sardegna n. 4 del 13/10/2009 (89pp) (in Italian).

Mummey, D.L., Smith, J.L., Bolton Jr., H., 1994. Nitrous oxide flux from a shrub-steppe ecosystem: sources and regulation. Soil Biol. Biochem. 26, 279-286.

Munné, A., Prat, N., 2004. Defining river types in a Mediterranean area: a methodology for the implementation of the EU Water Framework Directive. Environ. Manag. 33, 1-19.

Munné, A., Prat, N., 2009. Use of macroinvertebrate-based multimetric indices for water quality evalution in Spanish Mediterranean rivers: an intercalibration approach with the IBMWP index. Hydrobiologia 628, 203-225.

Muñoz, I., 2003. Macroinvertebrate community structure in an intermittent and a permanent Mediterranean stream (NE Spain). Limnetica 22, 107-116.

Múrria, C., Bonada, N., Ribera, C., Prat, N., 2010. Homage to the virgin of ecology, or why an aquatic insect unadapted to desiccation may maintain populations in very small, temporary Mediterranean streams. Hydrobiologia 653, 179-190.

Myers, N., Mittermeier, R.A., Mittermeier, C.G., da Fonseca, G.A.B., Kent, J., 2000. Biodiversity hotspots for conservation priorities. Nature 403, 853-858.

Nadeau, T.L., Rains, M.C., 2007. Hydrological connectivity between headwater streams and downstream waters: how science can inform policy. J. Am. Water Resour. Assoc. 43, 118-133.

Navarro-Ortega, A., Acuña, V., Batalla, R.., Blasco, J., Conde, C., Elorza, F.J., Elosegi, A. Francés, F., La-Roca, F., Muñoz, I., Petrovic, M., Picó, Y., Sabater, S., Sanchez-Vila, X., Schuhmacher, M., Barcelo, M., 2012. Assessing and forecasting the impacts of global change on Mediterranean rivers. The SCARCE Consolider project on Iberian basins. Environ. Sci. Pollut. Res. Int. 19, 918-933.

Navarro-Ortega, A., Acuña, V., Bellin, A., Burek, P., Cassiani, G., Choukr-Allah, R., Dolédec S., Elosegi, A., Ferrari, F., Ginebreda, A., Grathwohl, P., Jones, C., Rault, P.K., Kok, K. Koundouri, P., Ludwig, R.P., Merz, R., Milacic, R., Muñoz, I., Nikulin, G., Paniconi, C. Paunović, M., Petrovic, M., Sabater, L., Sabater, S., Skoulikidis, N.T., Slob, A., Teutsch, G., Voulvoulis, N., Barceló, D., 2015. Managing the effects of multiple stressors on aquatic ecosystems under water scarcity. The GLOBAQUA project. Sci. Total Environ. $15,503-504$.

Nikolaidis, N.P., Demetropoulou, L., Froebrich, J., Jacobs, C., Gallart, F., Prat, N., Lo Porto, A. Campana, C., Papadoulakis, V., Skoulikidis, N., Davy, T., Bidoglio, G., Bouraoui, F., Kirkby, M., Tournoud, M.G., Polesello, S., Barberá, G.G., Cooper, D., Gomez, R., Sánchez-Montoya, M.M., Latron, J., De Girolamo, A.M., Perrin, J.L., 2013. Towards sustainable management of Mediterranean river basins: policy recommendations on management aspects of temporary streams. Water Policy 15, 830-849.

Nikolaidis, N., Skoulikidis, N., Papadoulakis, V., Tsakiris, K., Kalogerakis, N., 2009. Management Plans for the agricultural basin of Evrotas River, technical report. In: Nikolaidis, N., Kalogerakis, N., Skoulikidis, N. (Eds.), Environmental Friendly Technologies for Rural Development. LIFE ENVIRONMENT, LIFE05 ENV/GR/000245 (EnviFriendly).

Novais, M.H., Morais, M.M., Rosado, J., Dias, L.S., Hoffmann, L., Ector, L., 2014. Diatoms of temporary and permanent watercourses in Southern Europe (Portugal). River Res. Applic. 30, 1216-1232.

Oueslati, O. De Girolamo, A.M., Abouabdillah, A., Kjeldsen, T.R., Lo Porto, A., 2015. Classifying flow regimes of Mediterranean streams using multivariate analysis. Hydrol. Process. 29, 4666-4682.

Papastergiadou, E. Manolaki, P. 2012. Developing an assessment system of RM-4 \& RM-5 river types for Cyprus Rivers. Final Report of Project TAY 84/2009. Natural Resources and Environment. Water Development Department, Ministry of Agriculture.

Pavlineri, N., Skoulikidis, N.T., Tsihrintzis, V.A., 2017. Constructed floating wetlands: a review of research, design, operation and management aspects, and data meta-analysis. Chem. Eng. 308, 1120-1132.

Peck, D.V., Herlihy, A.T., Hill, B.H., Hughes, R.M., Kaufmann, P.R., Klemm, D.J., Lazorchak J.M., McCormick, F.H., Peterson, S.A., Ringold, S.A., Magee, T., Cappaert, M., 2006. Environmental monitoring and assessment program-surface waters western pilot study: field operations manual for wadeable streams. EPA/620/R-06/003. Office of Research and Development. US Environmental Protection Agency, Corvallis, Oregon. Peterjohn, W.T., Schlessinger, W.H., 1991. Factors controlling denitrification in a Chihuahuan desert ecosystem. Soil Sci. Soc. Am. J. 55, 1694-1701.

Petrakis, M., Giannakopoulos, C., Lemesios, G., 2012. Report on observed changes and responses to climate change worldwide and in Cyprus. CYPADAPT - development of a national strategy for adaptation to climate change adverse impacts in Cyprus. LIFE10 ENV/CY/000723. DELIVERABLE 1.1. National Observatory of Athens, Athens, Greece [online]. Available from:. http://cypadapt.uest.gr/wp-content/uploads/ DELIVERABLE1.1.pdf (Accessed March 17, 2016)

Petrovic, M., Ginebreda, A., Acuna, V., Batalla, R.J., Elosegi , A., Guasch, H., et al., 2011. Combined scenarios of chemical and ecological quality under water scarcity in the Mediterranean Rivers. Trends in Analytical Chemistry 30, 1269-1278.

Phillipsen, I.C., Lytle, D.A., 2013. Aquatic insects in a sea of desert: population genetic structure is shaped by limited dispersal in a naturally fragmented landscape. Ecography 36, 731-743.

Pinto, P., Rosado, J., Morais, M., Antunes, I., 2004. Assessment methodology for southern siliceous basins in Portugal. Hydrobiologia 516, 191-214.

Pires, A.M., Cowx, I.G., Coelho, M.M., 1999. Seasonal changes in fish community structure of intermittent streams in the middle reaches of the Guadiana basin, Portugal. J. Fish Biol. 54, 235-249.

Pires, A.M., Cowx, I.G., Coelho, M.M., 2000. Benthic macroinvertebrate communities of intermittent streams in the middle reaches of the Guadiana Basin (Portugal). Hydrobiologia 435, 167-175.

Poff, N.L., Ward, J.V., 1805-1818. Implications of streamflow variability and predictability for lotic community structure: a regional analysis of streamflow patterns. Can. J. Fish. Aquat. Sci. 46.

Poff, L., Zimmerman, J.K., 2010. Ecological responses to altered flow regimes: a literature review to inform the science and management of environmental flows. Freshw. Biol. $55,194-205$.

Poff, N.L., Allan, J.D., Bain, M.B., Karr, J.R., Prestegaard, K.L., Richter, B.D., Sparks, R.E., Stromberg, J.C., 1997. The natural flow regime: a paradigm for river conservation and restoration. Bioscience 47, 769-784.

Prat, N., 2002. El proyecto GUADALMED sobre el Estado Ecológico de los ríos mediterráneos. Limnética 21, 1-3.

Prat, N., Ward, J.V., 1994. The tarneel river. In: Margalef, R. (Ed.), Limnology Now: A Paradigm of Planetary Problems. Elsevier Sciences B.V.

Prat, N., Gallart, F., von Schiller, D., Polesello, S., García-Roger, E.M., Latron, J., Rieradevall, M., Llorens, P., Barberá, G.G., Brito, D., De Girolamo, A.M., Dieter, D., Lo Porto, A., Buffagni, A., Erba, S., Nikolaidis, N.P., Querner, E.P., Tournoud, M.G., Tzoraki, O., Skoulikidis, N., Gómez, R., Sánchez-Montoya, M.M., Tockner, K., Froebrich, J., 2014. The mirage toolbox: an integrated assessment tool for temporary streams. River Res. Appl. 30, 1318-1334.

Pringle, C., 2003. What is hydrologic connectivity and why is it ecologically important? Hydrol. Process. 17, 2685-2689.

Ramos, T.B., Gonçalves, M.C., Branco, M.A., Brito, D., Rodrigues, S., Sánchez-Pérez, J.M., Sauvage, S., Prazeres, Â., Fernandes, M.L., Martins, J.C., Pires, F.P., 2015. Sediment and nutrient dynamics during storm events in the Enxoé temporary river, southern Portugal. Catena 127, 177-190.

Regione Autonoma Friuli Venezia Giulia, 2014. Piano Regionale di Tutela delle Acque. Analisi conoscitiva, p. 816 (in Italian).

Regione Siciliana, 2010. Piano di gestione del distretto idrografico della sicilia - Allegati al piano di gestione. Allegato 01-a, Tipizzazione dei corpi idrici superficiali - fiumi. Marzo 2010 (65pp) (in Italian).

Robson, B.J., Chester, E.T., Austin, C.M., 2011. Why life history information matters: drought refuges and macroinvertebrate persistence in non-perennial streams subject to a drier climate. Mar. Freshw. Res. 62, 801-810.

Robson, B.J., Hogan, M., Forester, T., 2005. Hierarchical patterns of invertebrate assemblage structure in stony upland streams change with time and flow permanence. Freshw. Biol. 50, 944-953.

Romani, A.M., Amalfitano, S., Artigas, J., Fazi, S., Sabater, S., Timoner, X., Ylla, I., Zoppini, A 2013. Microbial biofilm structure and organic matter use in Mediterranean streams. Hydrobiologia 719, 43-58.

Rosado, J., Morais, M., 2010. Climate change and water scarcity: from a global scale to particular aspects in Mediterranean region (Portugal). Science and Technology for Environmental Studies. Experiences from Brazil, Portugal and Germany. Universidade Federal de Santa Catarina, Brasil, pp. 15-27.

Rosado, J., Morais, M., Serafim, A., Pedro, A., Silva, H., Potes, M., Brito, D., Salgado, R., Neves, R., Lillebø, A., Chambel, A., Pires, V., Gomes, C.P., Pinto, P., 2012. Key long term patterns for the management and Conservation of temporary Mediterranean streams: a case study of the Pardiela river, southern Portugal (Guadiana catchment). In: Boon, P.J., Raven, P.J. (Eds.), River Conservation and Management. John Wiley and Sons, Ltd. (412pp).

Rosado, J., Morais, M., Tockner, K., 2014. Mass dispersal of terrestrial organisms during first flush events in a temporary stream. River Res. Appl. 31, 912-917.

Rossel, F., 2002. Surface water resources. Objective 1 - output 1.4.1. In: Water Development Department and FAO (Ed.), Reassessment of the Island's Water Resources and Demand. TCP/CYP/8921 Volume I. Water Development Department. FAO- Land and Water Development Division, Nicosia :p. 62 [online]. Available from:. http://www.moa.gov.cy/moa/ wdd/wdd.nsf/all/4EE924785C3708F1C225777C00351D3F/\$file/1_4_1.pdf (Accessed September 27, 2015).

Ruiz-Olmo, J., Jiménez, J., 2009. Diet diversity and breeding of top predators are determined by habitat stability and structure: a case study with the Eurasian otter (Lutra lutra L.). Eur. J. Wildl. Res. 55, 133-144.

Ruiz-Olmo, J., Jiménez, J., Chacón, W., 2007. The importance of ponds for the otter (Lutra lutra) during drought periods in Mediterranean ecosystems: a case study in Bergantes River. Mammalia 71, 16-24. 
Ruiz-Olmo, J., López-Martín, J.M., Palazón, S., 2001. The influence of fish abundance on the otter (Lutra lutra) populations in Iberian Mediterranean habitats. J. Zool. 254, 325-336.

Ruiz-Olmo, J., Olmo-Vidal, J.M., Mañas, S., Batet, A., 2002. The influence of resource seasonality on the breeding patterns of the Eurasian otter (Lutra lutra) in Mediterranean habitats. Can. J. Zool. 80, 2178-2189.

Ryder, D.S., Boulton, A.J., 2005. Redressing the limnological imbalance: trends in aquatic ecology, management and conservation in Australia. Hydrobiologia 552, 159-166.

Sabater, S., Tockner, K., 2010. Effects of hydrological alterations on the ecological quality of river ecosystems. In: Sabater, S., Barcelo, D. (Eds.), Water scarcity in the mediterranean: perspectives under global change. Springer, Heidelberg.

Sabater, S., Guasch, H., Muñoz, I., Romaní, A., 2006. Hydrology, light and the use of organic and inorganic materials as structuring factors of biological communities in Mediterranean streams. Limnetica 25, 335-348.

Sabater, S., Joao Feio, M., Graca, M.A.S., Munoz, I., Romani, A.M., 2009. The Iberian Rivers. In: Tockner, K., Uehlinger, U., Robinson, C.T. (Eds.), Rivers of Europe. Academic Press, London, UK.

Sánchez-Montoya, M.M., Moleón, M., Sánchez-Zapata, J.A., Tockner, K., 2016. Dry riverbeds: corridors for terrestrial vertebrates. Ecosphere http://dx.doi.org/10.1002/ecs2. 1389.

Sánchez-Montoya, M.M., Vidal-Abarca, M.R., Puntí, T., Poquet, J.M., Prat, N., Rieradevall, M., Alba-Tercedor, J., Zamora-Muñoz, C., Toro, M., Robles, S., Álvarez, M., Suárez, M.L., 2009. Defining criteria to select reference sites in Mediterranean streams. Hydrobiologia 619, 39-54.

Sánchez-Montoya, M.M., Vidal-Abarca, M.R., Suárez, M.L., 2010. Comparing the sensitivity of diverse macroinvertebrate metrics to a multiple stressor gradient in Mediterranean streams and its influence on the assessment of ecological status. Ecol. Indic. $10,896-904$

Sánchez-Montoya, M.M., von Schiller, D., Ruhí, S.P.G., Proia, L., Miñano, J., Vidal-Abarca, M.R., Suárez, M.L., Tockner, K., 2016. Responses of ground-dwelling arthropods to surface flow drying in channels and adjacent habitats along Mediterranean streams. Ecohydrology (in press).

Singh, V.P., Woolhiser, D.A., 2002. Mathematical modelling of watershed hydrology. J. Hydr. Eng. 7, 270-292.

Skoulikidis, N., 2002. Hydrochemical character and spatiotemporal variations in a heavily modified river of Western Greece. Environ. Geol. 43, 814-824.

Skoulikidis, N., 2009. The environmental state of rivers in the Balkans: a review within the DPSIR framework. Sci. Total Environ. 407, 2501-2516.

Skoulikidis, N., Amaxidis, Y., 2009. Origin and dynamics of dissolved and particulate nutrients in a minimally disturbed Mediterranean river with intermittent flow. J. Hydrol. 37, 218-229.

Skoulikidis, N.T., Vardakas, L., Amaxidis, Y., Michalopoulos, P., 2017. Biogeochemical processes controlling aquatic quality during drying and rewetting events in a Mediterranean non-perennial river reach. Sci. Total Environ. 575, 378-389.

Skoulikidis, N., Vardakas, L., Karaouzas, I., Economou, A., Dimitriou, E., Zogaris, S., 2011. Assessing water stress in Mediterranean lotic systems: insights from an artificially intermittent river in Greece. Aquat. Sci. 73, 581-597.

Smith, B., 1997. Water: a critical resource. In: King, R., Proudfoot, L., Smith, B. (Eds.), The Mediterranean: Environment and Society. Arnold, London, pp. 227-251.

Snelder, T.H., Datry, T., Lamouroux, N., Larned, S.T., Sauquet, E., Pella, H., Catalogne, C., 2013. Regionalization of patterns of flow intermittence from gauging station records. Hydrol. Earth Syst. Sci. 17, 2685-2699.

Sorace, A., Formichetti, P., Boano, A., Andreani, P., Gramegna, C., Mancini, L., 2002. The presence of a river bird, the dipper, in relation to water quality and biotic indices in central Italy. Environ. Pollut. 118, 89-96.

Sparling, D.W., Fellers, G.M., McConnell, L.L., 2001. Pesticides and amphibian population declines in California, USA. Environ. Toxicol. Chem. 20, 1591-1595.

Stanley, E.H., Fisher, S.G., Grimm, N.B., 1997. Ecosystem expansion and contraction in streams. Bioscience 47, 427-435.

Stanley, E.H., Fisher, S.G., Jones, J.B., 2004. Effects of water loss on primary production: a landscape-scale model. Aquat. Sci. 66, 130-138.

Stefanidis, K., Panagopoulos, Y., Psomas, A., Mimikou, M., 2016. A methodological approach for evaluating ecological flows using ecological indicators: a case study in River Pinios, Greece. 1st GLOBAQUA Intern. Conf.Managing The Effects Of Multiple Stressors on Aquatic Ecosystems Under Water Scarcity, 11-12 January 2016, Freising (Germany).

Steward, A.L., Marshall, J.C., Sheldon, F., Harch, B., Choy, S., Bunn, S.E., Tockner, K., 2011. Terrestrial invertebrates of dry river beds are not simply subsets of riparian assemblages. Aquat. Sci. 73, 551-566.

Steward, A.L., von Schiller, D., Tockner, K., Marshall, J.C., Bunn, S.E., 2012. When the rivers runs dry: human and ecological values of dry riverbeds. Front. Ecol. Environ. 10, 202-209.

Suárez, M.L., Vidal-Abarca, M.R., 2008. Un índice para valorar el estado de conservación de las ramblas mediterráneas (Indice de Alteración de Ramblas = IAR). Tecnología del Agua 239, 67-78.

Suárez, M.L., Sánchez-Montoya, M.M., Gómez, R., Arce, M.I., del Campo, R., Vidal-Abarca, M.R., 2016. Functional response of aquatic invertebrate communities along two natural stress gradients (water salinity and flow intermittence) in Mediterranean streams. Aquat. Sci. n/a.

TempQsim Consortium, 2006. Critical issues in the water quality dynamics of temporal rivers-evaluation and recommendations of the tempQsim project. In: Froebrich, J., Bauer, M. (Eds.), Enduser Summary. Hannover, Germany.

Tierno de Figueroa, J.M., Lopez-Rodriguez, M.J., Fenoglio, S., Sanchez-Castillo, P., Fochetti, R., 2013. Freshwater biodiversity in the rivers of the Mediterranean basin. Hydrobiologia 719, 137-186.

Timoner, X., 2014. Stream Biofilm Responses to Flow Intermittency. PhD thesis. University of Girona.
Timoner, X., Acuña, V., Frampton, L., Pollard, P., Sabater, S., Bunn, S.E., 2014b. Biofilm functional responses to the rehydration of a dry intermittent stream. Hydrobiologia 727, $185-195$.

Timoner, X., Borrego, C.M., Acuña, V., Sabater, S., 2014c. The dynamics of biofilm bacterial communities is driven by flow wax and wane in a temporary stream. Limnol. Oceanogr. 59, 2057-2067.

Timoner, X., Buchaca, T., Acuña, V., Sabater, S., 2014a. Photosynthetic pigment changes and adaptations in biofilms in response to flow intermittency. Aquat. Sci. 76, 565-578.

Tockner, K., Uehlinger, U., Robinson, C.T., Tonolla, D., Siber, R., Peter, F.D., 2009. Introduction to European Rivers. In: Tockner, K., Uehlinger, U., Robsinson, C.T. (Eds.), Rivers of Europe. Academic Press, London, pp. 1-23.

Tornés, E., Ruhí, A., 2013. Flow intermittency decreases nestedned and specialization of diatom communities in Mediterranean rivers. Freshw. Biol. 58, 2555-2566.

Tzoraki, O., Nikolaidis, N., 2007. A generalized framework for modeling the hydrologic and biogeochemical response of a Mediterranean temporary river basin. J. Hydrol. $346,112-121$.

Tzoraki, O.A., Dörflinger, G., Kathijotes, N., Kontou, A., 2014. Nutrient-based ecological consideration of a temporary river catchment affected by a reservoir operation to facilitate efficient management. Water Sci. Technol. 69, 847-854.

UNEP, 1992. World Atlas of Desertification. Edward Arnold, London.

UNEP/MAP, 2003. Riverine Transport of Water, Sediments and Pollutants to the Mediterranean Sea. UNEP/Mediterranean Action Plan, Athens, Greece.

Uys, M.C., O'Keeffe, J.H., 1997. Simple words and fuzzy zones: early directions for temporary river research in South Africa. Environ. Manag. 21, 517-553.

Vander Vorste, R., Corti, R., Sagouis, A., Datry, T., 2015a. Invertebrate communities in gravel-bed, braided rivers are highly resilient to flow intermittence. Freshw. Sci. (in press).

Vander Vorste, R., Malard, F., Datry, T., 2015b. Is drift the primary process promoting the resilience of river invertebrate communities? A manipulative field experiment in an alluvial, intermittent river. Freshw. Biol. (in press).

Vardakas, L., Kalogianni, E., Zogaris, S., Koutsikos, N., Vavalidis, T., Koutsoubas, D. Skoulikidis, N., 2015. Distribution patterns of fish assemblages in an Eastern Mediterranean intermittent river. Knowl. Manag. Aquat. Ecosyst. 416, 30.

Vardakas, L., Tzoraki, O., Skoulikidis, N., Economou, A.N., Nikolaidis, N., 2009. Developing a preliminary river basin management plan for the Evrotas River, Southern Greece. Workshop WG3: Inter-Comparison of the First RBMP of the European Member States Regarding Implementation of Measures to Reduce Nutrient Losses from Rural Areas 18-19 May 2008, Wageningen, Holland.

Vidal-Abarca, M.R., 1990. Los ríos de las cuencas áridas y semiáridas: Una perspectiva ecológica comparativa y de síntesis. Scientia gerundensis 16, 219-228.

Vila-Gispert, A., Garcia-Berthou, E., Moreno-Amich, R., 2002. Fish zonation in a Mediterranean stream: effects of human disturbances. Aquat. Sci. 64, 163-170.

Vogiatzakis, I.N., Mannion, A.M., Griffiths, G.H., 2006. Mediterranean ecosystems: problems and tools for conservation. Prog. Phys. Geogr. 30, 175-200.

Vörösmarty, C.J., McIntyre, P.B., Gessner, M.O., Dudgeon, D., Prusevich, A., Green, P., Glidden, S., Bunn, S.E., Sullivan, C.A., Reidy Liermann, C., Davies, P.M., 2010. Global threats to human water security and river biodiversity Nature. 467, pp. 555-561.

von Schiller, D., Acuña, V., Graeber, D., Martí, E., Ribot, M., Sabater, S., Timoner, X., Tockner, K., 2011. Contraction, fragmentation and expansion dynamics determine nutrient availability in a Mediterranean forest stream. Aquat. Sci. 73, 485-498.

von Schiller, D., Marcé, R., Obrador, B., Gómez-Gener, L., Casas-Ruiz, J.P., Acuña, V., Koschorrek, M., 2014. Carbon dioxide emissions from dry watercourses. Inland Waters 4, 377-382.

Water Development Department. Annual Report, 2014. Water Development Department.[online]. Available:. http://www.moa.gov.cy/moa/wdd/wdd.nsf/All/ FC6C018F38B90DB7C2257E820030F17A/\$file/FINAL_ENGLISH_2014.pdf (Accessed September 27, 2015).

Williams, D.D., 1996. Environmental constraints in temporary fresh waters and their consequences for the insect fauna. J. N. Am. Benthol. Soc. 15, 634-650.

Williams, D.D., 2008. The Biology of Temporary Waters. Oxford University Press, New York.

Wishart, M., 2000. The terrestrial invertebrate fauna of a temporary stream in southern Africa. Afr. Zool. 35, 193-200.

Wriedt, G., Van der Velde, M., Aloe, A., Bouraoui, F., 2009. Estimating irrigation water requirements in Europe. J. Hydrol. 373, 527-544.

WWF, 2003. WWF's Water and Wetland Index. Critical Issues in Water Policy across Europe. World Wide Fund For Nature, Madrid, Spain.

Yassoglou, N.J., Catacousinos, D., Kouskolekas, A., 1964. Land use in the semi-arid zone of Greece. Land Use in Semi-arid Mediterranean Climates, UNESCO, International Geographical Union Symposium, Iraklion (Greece), 19-26 September 1962, pp. 63-67.

Zogaris, S., Chatzinikolaou, Y., Koutsikos, N., Oikonomou, E., Giakoumi, S., Economou, A.N. Vardakas, L., Segurado, P., Ferreira, M.T., 2012. Assessment of fish assemblages in Cyprus Rivers for the implementation of Directive 2000/60/EC. Specialized Consultancy Services for the Assessment of Fish Assemblages in Cyprus Rivers - Implementation of the Directive 2000/60/EC. Final Report of Second Phase of the Project. Hellenic Center for Marine Research - Institute of Marine Biological Resources and Inland Waters/ Instituto Superior de Agronomia, Universidade Técnica de Lisboa, p. 205.

Zoumides, C., Bruggeman, A., Zachariadis, T., Pashiardis, S., 2013. Quantifying the poorly known role of groundwater in agriculture: the case of Cyprus. Water Resour. Manag. 27, 2501-2514.

EEA, 2016. Biogeographical regions. http://www.eea.europa.eu/data-and-maps/data/ biogeographical-regions-europe-3.

Tzoraki, O., Nikolaidis, N., Amaxidis, Y., Skoulikidis, N., 2007. In-stream biogeochemical processes of a temporary river. Environ. Sci. Technol. 41, 1225-1231. 